\title{
Harmful algal blooms and environmentally friendly control strategies in Japan
}

\author{
Ichiro Imai ${ }^{1,4} \cdot$ Nobuharu Inaba ${ }^{2} \cdot$ Keigo Yamamoto $^{3}$
}

Received: 27 December 2020 / Accepted: 19 April 2021 / Published online: 30 June 2021

(c) The Author(s) 2021

\begin{abstract}
The presence and status of harmful algal blooms (HABs) in Japan are reviewed, revealing a decrease in red tides; however, toxic blooms are found to be increasing in western Japan. Environmentally friendly control strategies against HABs are also compared with integrated agricultural pest management. Very high densities $\left(10^{5}-10^{8} \mathrm{CFU} / \mathrm{g}\right)$ of algicidal and growthinhibiting bacteria were found in biofilm on seagrass and seaweed surfaces and in surrounding coastal seawater. The situation in freshwater ecosystems is similar to coastal seas for toxic cyanobacterium, Microcystis aeruginosa, and aquatic plants. These findings offer new insights into the ecology of influential bacteria and harmful algae, suggesting that protection and restoration of native seagrasses and seaweeds in coastal marine environments should be implemented to suppress HABs. Diatom blooms were successfully induced with bottom sediment perturbation to prevent the occurrence of harmful flagellates such as Chattonella spp. and Alexandrium catenella in the Seto Inland Sea; however, this method requires robust and reproducible verification. "Sato-Umi" is a helpful concept for HAB control in the sea and freshwater ecosystems when adequately managed by people (e.g., appropriate bottom perturbation; protection and restoration of seaweeds, seagrasses, and aquatic plants; application of polycultures of fish, seaweeds, etc.).
\end{abstract}

Keywords Harmful algal bloom · Environmentally friendly strategy $\cdot$ Diatom $\cdot$ Sediment perturbation $\cdot$ Algicidal bacteria $\cdot$ Seagrass bed $\cdot$ Aquatic plant $\cdot$ Sato-Umi

\section{Introduction}

The sea covers approximately $70 \%$ of the Earth's surface. The sea was the birthplace of life and is home to an array of marine life comprising well over a million species. Humans receive numerous ecosystem services from the sea, including

Published with support by the Japan Society for the Promotion of Science (JSPS) KAKENHI grant no. JP19HP2002.

Ichiro Imai

imai1ro@fish.hokudai.ac.jp

1 Present Address: Lake Biwa Museum, 1091 Oroshimo-cho, Kusatsu, Shiga 525-0001, Japan

2 Civil Engineering Research Institute for Cold Region, Public Works Research Institute, 1-3-134 Hiragishi, Toyohira-ku, Sapporo, Hokkaido 062-8602, Japan

3 Research Institute of Environment, Agriculture and Fisheries, Osaka Prefecture, 4-4-2 Shakudo, Habikino, Osaka 583-0862, Japan

4 Hokkaido University, Hakodate, Japan provisions (e.g., food, water, and energy), regulations (e.g., climate, erosion and flood control, pollination, and decomposition), cultural activities (e.g., recreation, physical and mental health benefits, aesthetic, etc.), and support (e.g., species habitat, maintenance of genetic diversity, etc.; Millennium Ecosystem Assessment 2007). Converting the benefits of the ocean into direct monetary values is difficult; however, Constanza et al. (1997) evaluated the total annual ecosystem services on Earth at 33.3 trillion USD, of which the ocean's contribution was estimated to be $\sim 20.9$ trillion USD. Because these values suffer from such wide ranges of uncertainty, they are assumed to be underestimated. As the total annual human productivity is estimated to be $\sim 18$ trillion USD per year (Constanza et al. 1997), the importance of the oceans is self-evident.

The coastal area of the ocean, which is considered to be the area of shallow sea to the intertidal zone where ebb and flow tides are observed to a water depth of approximately $200 \mathrm{~m}$, is rich in marine life with high levels of biodiversity and biological productivity (Yanagi 2006). Terrestrial regions bordering such coastal areas generally have high population 
density, thereby causing anthropogenic environmental issues such as inflow of pollutants resulting in eutrophication from a variety of human activities, a crucial factor in the occurrence of harmful algal blooms (HABs) (Anderson et al. 2002; Imai et al. 2006a; Heisler et al. 2008).

Since ancient times, Japanese people have utilized a wide variety of aquatic organisms from the sea, rivers, lakes, etc., for food. The variety of seafood in Japan is extensive, and unique recipes and preservation methods have been developed over time. According to the United Nations Food and Agriculture Organization (UNFAO), Japan's per-capita supply of seafood is the largest in the world, and with a population of more than one hundred million people, more fish are consumed in Japan, per capita, than anywhere else in the world.

Seafood is supplied by fisheries from pelagic, offshore, coastal, and aquaculture sources. In particular, the aquaculture industry, with its controllable and methodical production, plays a crucial role in stabilizing supplies. The aquaculture industry produced $23 \%$ (1.03 million $\mathrm{t}$ ) of total production and $32 \%$ (486.1 billion JPY) of the monetary value of fisheries in 2018 (MAFF 2020); however, since aquaculture industries operate in relatively calm coastal bay areas, harmful red tides have recurrently plagued the fish and shellfish industries.

The most common organisms responsible for harmful red tides are raphidophytes, dinoflagellates, and diatoms. Harmful flagellates usually kill fish and bivalves, whereas diatoms can cause bleaching of the cultured red alga nori Neopyropia yezoensis. It is estimated that a single red tide incident can result in economic damage valued at greater than 1 billion JPY (Itakura and Imai 2014; Imai 2017a).

This review summarizes the occurrence of HABs in the coastal waters of Japan. In terms of preventive strategies, we present feasible and environmentally friendly measures. Furthermore, the concepts of preventive strategies are compared with those of pest control in the agricultural field, which have long been studied extensively in literature. The environmentally friendly, preventive strategies against HABs discussed in this review are also considered to be an integral part of the Sato-Umi concept (Yanagi 2008). Additionally, concerning the prevention of toxic cyanobacterial blooms in freshwater ecosystems, we examined a recent discovery of cyanobactericidal bacteria that attach to and inhabit the surface of aquatic plants in great abundance, and proposed a preventive strategy through the effective utilization of aquatic plants.

\section{Occurrence of HABs in Japan}

Phytoplankton are floating microalgae that perform photosynthesis and play an essential role as primary producers in the food webs of the marine ecosystem, thus ultimately supporting the production of seafood for human consumption. However, some species of phytoplankton proliferate rapidly, causing harmful "red tides" that are detrimental to marine life (Okaichi 2004; Imai et al. 2006a; Itakura and Imai 2014; Sakamoto et al. 2021), while other species have toxins in their cells that are transferred and amassed in higher-level organisms (e.g., bivalves) through the food web. Such accumulation of toxins, and the potential resulting death of higher-order predators such as fish, birds, marine mammals, and humans, have caused significant problems in the bivalve aquaculture industries, human health, and the environmental conditions (Imai et al. 2006a; Anderson 2017; Trainer et al. 2020; Wells et al. 2020; Sakamoto et al. 2021).

The phenomenon of such increases in the population of algal species is referred to be "blooms." Algae that adversely affect human and marine life are known as harmful algae (HA), and the proliferation of HA results in harmful algal blooms (HABs) (Hallegraeff 1993). HABs can be classified into four types according to their causative species (Hallegraeff 1993; Imai et al. 2006a): (1) biomass blooms, which occur when harmless phytoplankton species proliferate into a large amount of organic matter, and upon death, dissolved oxygen is consumed, causing anoxia in seawater and death of marine life; (2) noxious red tides, which occur when deleterious phytoplankton species form red tides and cause mass mortality of marine life, particularly fish and bivalves in aquaculture; (3) toxic blooms, which are caused when poisonous microalgal species are transferred to higher trophic levels of marine and terrestrial life (including humans) through food webs, deleteriously affecting the higher-level organisms; (4) harmful diatom blooms, which occur when common diatom species form red tides during nori (seaweed) aquaculture, entirely consuming seawater nutrients and reducing the quality, and therefore value, of nori products. Red tides are a phenomenon where the discoloration of seawater results from the growth and accumulation of phytoplankton, and three types of HABs except for toxic blooms can usually be characterized by the term "red tides." However, as even toxic phytoplankton species can increase to levels that cause discoloration of seawater (albeit very rarely), this may also be called a "red tide" (Yamamoto et al. 2009a, 2017).

Table 1 summarizes the types of issues caused by HABs of major causative species in Japanese coastal waters. The damage inflicted by red tides is primarily confined to aquacultures, where various HAB species have resulted in mass mortality of fish and bivalves, and seaweed bleaching. In bivalve aquaculture, many toxic phytoplankton species can poison shellfish, and the resultant shipping restrictions have had significant economic repercussions (Suzuki 2017). Ciguatera fish poisoning (CFP) occurs when humans eat toxified fish that have accumulated toxins of toxic dinoflagellates attached to seaweed via direct consumption or food 
Table 1 Major types and causative organisms of HABs in Japanese coastal sea

\begin{tabular}{|c|c|c|}
\hline Category & Causative organism & Remark \\
\hline \multirow[t]{10}{*}{ Fish kill } & Raphidophyceae & \\
\hline & Chattonella antiqua & Largest impact on yellowtail \\
\hline & C. marina & \\
\hline & C. ovata & \\
\hline & Heterosigma akashiwo & Serious damage in Kagoshima Bay \\
\hline & Dinophyceae & \\
\hline & Karenia mikimotoi & Killing mollusks, crustaceans, etc. \\
\hline & Margalefidinium polykrikoides & Killing mollusks, crustaceans, etc. \\
\hline & Dictyochophyceae & \\
\hline & Pseudochattonella verruculosa & Blooming at low temperature $\left(<15^{\circ} \mathrm{C}\right)$ \\
\hline \multirow[t]{2}{*}{ Bivalve kill } & Dinophyceae & \\
\hline & Heterocapsa circularisquama & Introduced from southern China \\
\hline \multirow[t]{3}{*}{ Biomass bloom } & Dinophyceae & \\
\hline & Noctiluca scintillans & Most frequent red tides in the world \\
\hline & Gonyaulax polygramma & Massive damage (807 million JPY) in 1994 \\
\hline \multirow[t]{10}{*}{ Nori (Neopyropia) bleaching } & Bacillariophyceae & Blooms in nori aquaculture season \\
\hline & Eucampia zodiacus & \\
\hline & Coscinodiscus wailesii & \\
\hline & Rhizosolenia imbricata & \\
\hline & Asteroplanus karianus & \\
\hline & Chaetoceros spp. & \\
\hline & Skeletonema spp. & \\
\hline & Thalassiosira spp. & \\
\hline & Dinophyceae & \\
\hline & Akashiwo sanguinea & \\
\hline \multirow[t]{4}{*}{ Paralytic shellfish poisoning (PSP) } & Dinophyceae & \\
\hline & Alexandrium catenella (group I) & Formerly Alexandrium tamarense \\
\hline & Alexandrium pacificum (group IV) & Formerly Alexandrium catenella \\
\hline & Gymnodinium catenatum & \\
\hline \multirow[t]{5}{*}{ Diarrhetic shellfish poisoning (DSP) } & Dinophyceae & \\
\hline & Dinophysis fortii & Mixotroph feeding Mesodinium \\
\hline & D. acuminata & \\
\hline & D. caudata & \\
\hline & Prorocentrum lima & Epiphytic dinoflagellate to seaweeds \\
\hline \multirow[t]{2}{*}{ Ciguatera fish poisoning (CFP) } & Dinophyceae & \\
\hline & Gambierdiscus toxicus & Epiphytic dinoflagellate to seaweeds \\
\hline
\end{tabular}

web interactions (Yasumoto et al. 1977; Adachi 2016). In addition, the damage to marine life inflicted by red tides is complicated, as larval mortality of important species will remain unnoticed until poor catches are observed in subsequent fishing seasons. It was reported that red tides of the harmful raphidophyte Heterosigma akashiwo killed a large quantity of juvenile sockeye salmon that had descended to Puget Sound from lakes on the west coast of the USA en route to the Arctic Sea, having a deleterious effect on returning resources (Rensel et al. 2010). As described above, various harmful algae have an array of adverse effects on marine life and human beings.

\section{Noxious red tides}

The following are the major red-tide-causing plankton species that have caused large-scale mortality of marine life in coastal areas of Japan: Chattonella spp. (C. antiqua, $C$. marina, and $C$. ovata) belonging to Raphidophyceae have inflicted the greatest damage to farmed fish, especially yellowtail Seriola quinqueradiata. The dinoflagellate Karenia mikimotoi is the second most important killer of fish in the region. Heterocapsa circularisquama is a unique dinoflagellate that selectively kills bivalves, which usually graze phytoplankton. Cochlodinium polykrikoides (currently called 
Margalefidinium polykrikoides) is the most violent red tide dinoflagellate in neighboring Korea. Heterosigma akashiwo (Raphidophyceae) and Noctiluca scintillans (Dinophyceae) are other important species creating red tides with high frequency.

Aquaculture, especially fish culture, is a key industry in the coastal areas of western Japan, where the incidence of red tides is widespread, including those driven by harmful species. Figure 1 shows the long-term changes in red tide frequencies, and correlated fishery damage, for the Seto Inland Sea and coastal areas of Kyushu (Fisheries Agency 2020a; b). In the Seto Inland Sea, the number of red tides increased linearly during the period of high economic growth from the 1960s to the mid-1970s. In this era of progress, industrial production flourished under the new industrial city initiative, and populations concentrated in large cities; and as a result, increasing volumes of industrial and domestic wastewater were discharged into the coastal seas, increasing pollution and eutrophication. Untreated human waste was dumped directly into the Seto Inland Sea as recently as the 1960s, further accelerating eutrophication. Annual red tide cases peaked in 1976 (299), and the highest number of mortalities of farmed yellowtail (14.2 million) due to the Chattonella red tide was recorded in 1972, inflicting an estimated $~ 7.1$ billion JPY in economic damage. The Law Concerning Special Measures for Conservation of the Environment of the Seto Inland Sea was enacted in 1973 in reaction to this historical Chattonella red tide. This legal regulation, in conjunction with new wastewater treatment measures, was effective at improving water quality (especially nutrient levels), and decreasing the incidence of red tides in the Seto Inland Sea (Imai et al. 2006a). Since then, the number of red tides has decreased to $\sim 100$ per year, and an even further decline has been recorded since 2015 , with just 58 recorded cases in 2019; however, fishery production is also declining in the Seto Inland Sea, and it has been suggested that water quality (namely nutrient levels) may have been over-improved to a state of oligotrophication (Yamamoto 2003).
Fig. 1 Occurrences of red tides in Seto Inland Sea from 1970 to 2019 (Fisheries Agency 2020a) and the Kyushu area from 1978 to 2019 (Fisheries Agency 2020b)
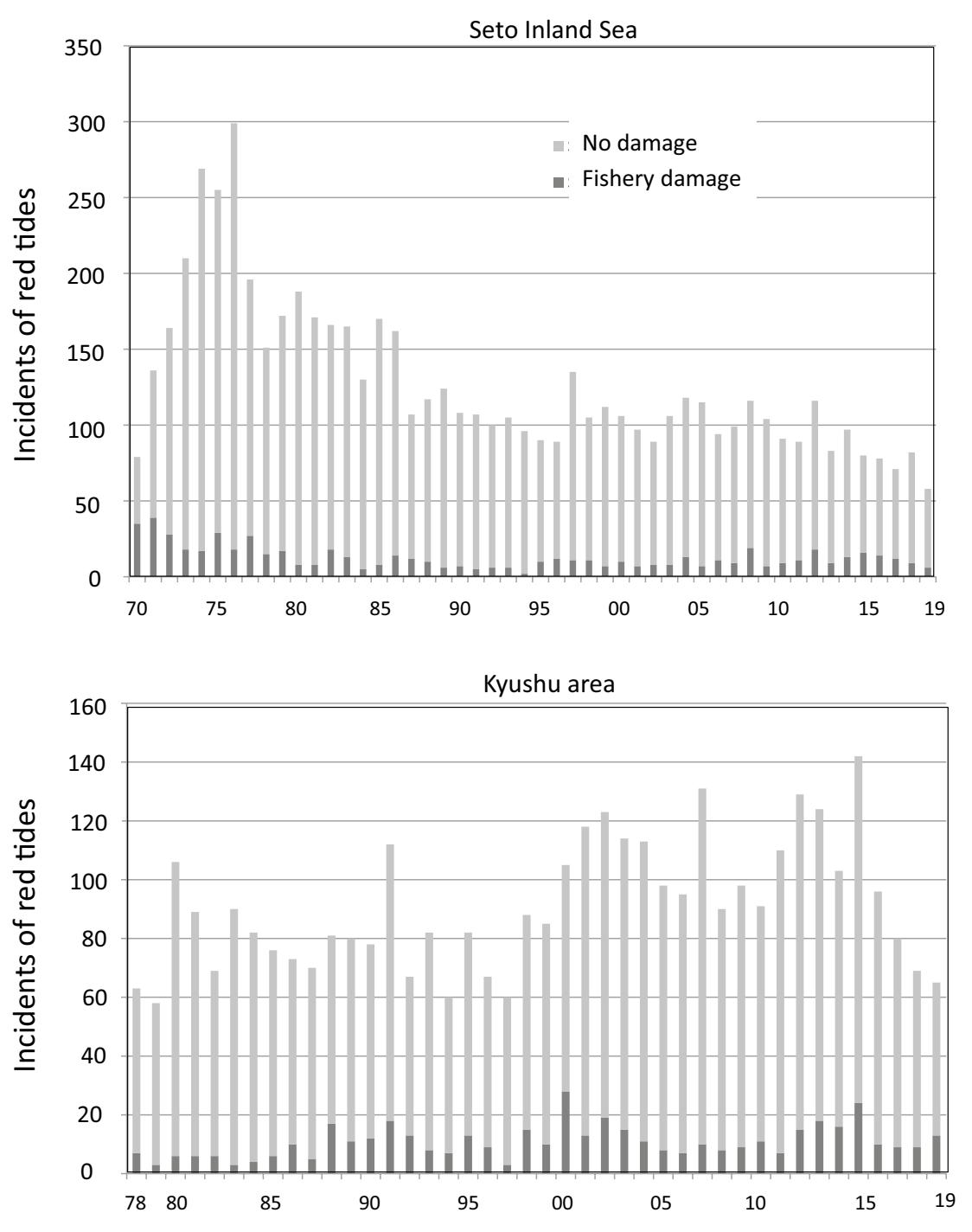
Examining red tide occurrences and fishery damage in the Kyushu area, the eutrophication and subsequent recovery of water quality are unclear, as in the case of the Seto Inland Sea (Fig. 1). Prior to 2000, annual red tide occurrences greater than or equal to 100 had been recorded only twice; however, this threshold was exceeded 10 times in the 16 years from 2000 to 2015 , and case numbers have showed a decreasing trend since then.

Table 2 presents the major fishery damage caused by red tides in Japanese coastal waters. Mortality caused by Chattonella spp. is the most prominent in both scale and frequency. Significant fishery damage caused by Chattonella has been a frequent occurrence since 1972, although no fishery damage exceeding 100 million JPY per year was reported in the Seto Inland Sea from 1990 to 2002. In 2003 and 2004, however, damage amounted to 1.3 billion JPY and 390 million JPY, respectively (totals include the damages inflicted by the dinoflagellate M. polykrikoides). Later, in the Yatsushiro Sea of Kyushu, Chattonella red tides caused 3.3 billion JPY and 5.3 billion JPY in 2009 and 2010, respectively, along with the fish kill of yellowtail.

The harmful dinoflagellate K. mikimotoi caused huge damage of 4.6 billion JPY due to the red tide in KumanoNada in 1984, shocking people involved in aquaculture industries. Since 1979, K. mikimotoi has continuously caused damage due to mortality of cultured fish and shellfish in the Seto Inland Sea. It was notable in 2012 that amberjack, red sea bream, yellowtail, abalone, etc., were killed with losses amounting to 1.5 billion JPY (1.2 billion JPY along the coast of Ehime Prefecture) in the Bungo Channel, western Seto Inland Sea. In 2017, about 600 million
JPY of damage was caused, mainly to tiger puffer (Takifugu rubripes) and yellowtail, etc., in the Kyushu area, mainly in Imari Bay. Other notable damages to the aquaculture industries include: the 1992 mass die-offs of pearl oyster Pinctada fucata (3.0 billion JPY) in Ago Bay, the oyster Crassostrea gigas (3.9 billion JPY) in Hiroshima Bay in 1998 due to $H$. circularisquama, and the yellowtail kill due to M. polykrikoides in the Yatsushiro Sea resulting in total damage of 4.0 billion JPY in 2000. Diatom red tides have caused bleaching damage in nori aquaculture as well, and in the winter of 2000, the Ariake Sea experienced a 13.6 billion JPY decrease in production compared with the previous year. Therefore, there is an urgent social need for preventive strategies to decrease the frequency of such red tides.

The occurrence of red tides is related to the unique physiological, ecological, and lifecycle characteristics of the causative species, as well as the local environmental characteristics of the aquatic area (Imai 2012). Extensive monitoring data are necessary to best understand the mechanisms behind their occurrence and build an accurate predictive model, which requires targeted investigations into each species for every location, with the hope that the development of scientifically based strategies will contribute to the prevention, control, and eradication of HABs.

\section{Toxic blooms}

In the coastal waters of Japan, bivalve mollusks such as oyster Crassostrea spp., scallop Mizuhopecten yessoensis, and mussels Mytilus spp. are the most abundant aquaculture products, supporting livelihoods and supplementing

Table 2 Extensive economic damage to aquaculture ( $\geq 1$ billion JPY) caused by HABs (red tides) in the coastal sea of western Japan. Data partially modified from Itakura and Imai (2014)

\begin{tabular}{|c|c|c|c|c|}
\hline Year & Area & HAB species & Damaged organism & $\begin{array}{l}\text { Economic loss } \\
\text { (billion JPY) }\end{array}$ \\
\hline 1972 & Harima-Nada & Chattonella spp. & Yellowtail & 7.1 \\
\hline 1977 & Harima-Nada & Chattonella spp. & Yellowtail & 2.7 \\
\hline 1978 & Harima-Nada & Chattonella spp. & Yellowtail & 3.3 \\
\hline 1984 & Kumano-Nada & Karenia mikimotoi & Yellowtail, noble scallop, etc. & 4.6 \\
\hline 1991 & Aki-Nada, etc. & Karenia mikimotoi & Red sea bream & 1.5 \\
\hline 1992 & Ago Bay & Heterocapsa circularisquama & Pearl oyster & 3.0 \\
\hline 1995 & Kagoshima Bay & Heterosigma akashiwo & Yellowtail, amberjack, etc. & 1.0 \\
\hline 1998 & Hiroshima Bay & Heterocapsa circularisquama & Oyster & 3.9 \\
\hline 2000 & Yatsushiro Sea & Margalefidinium polykrikoides & $\begin{array}{l}\text { Yellowtail, amberjack, Japanese puff- } \\
\text { erfish, etc. }\end{array}$ & 4.0 \\
\hline $2000-2001$ & Ariake Sea & Diatoms & Nori (Neopyropia) & $>10$ \\
\hline 2003 & Harima-Nada & Chattonella spp. & Yellowtail, amberjack & 1.3 \\
\hline 2009 & $\begin{array}{l}\text { Yatsushiro Sea } \\
\text { Ariake Sea }\end{array}$ & Chattonella spp. & Yellowtail & 3.3 \\
\hline 2010 & Yatsushiro Sea & Chattonella spp. & Yellowtail & 5.3 \\
\hline 2012 & Bungo Channel & Karenia mikimotoi & Amberjack, red sea bream, etc. & 1.5 \\
\hline
\end{tabular}


diets. Moreover, shellfish on tidal flats, such as Manila clam Ruditapes philippinarum, offer recreational opportunities to interact with the sea through shellfish gathering.

In Japanese coastal waters, the main poisonings of useful bivalves have been reported to cause paralytic shellfish poisoning (PSP) and diarrhetic shellfish poisoning (DSP) (Fukuyo 2000; Imai and Itakura 2007; Kamiyama 2017; Suzuki 2017). When toxin concentrations exceeded permitted levels, shipping restrictions were self-imposed to prevent toxic bivalves from entering the market (Iioka 2017). DSP problems are caused by the dinoflagellate genus Dinophysis, being most commonly observed in northeast Japan. Surprisingly, DSP problems rarely occur in western Japan, even where the same Dinophysis species proliferate to much higher cell densities in the Seto Inland Sea (Imai et al. 2006a; Imai and Itakura 2007). Regarding the PSP problems in western Japan, sporadic and small-scale poisonings of Manila clams have occurred because of Alexandrium pacificum (formerly named A. catenella) in the Kii Channel, Bungo Channel, Kagoshima Prefecture, etc. (Imai et al. 2006a). Since the early 1990s, oysters and Manila clams have frequently been poisoned by Alexandrium catenella (group I; formerly named Alexandrium tamarense) in Hiroshima Bay, Harima Nada, Osaka Bay, Ise Bay, Mikawa Bay, etc. (Itakura et al. 2002; Ishida and Sonda 2003; Imai et al. 2006a). Abundant cysts have also been confirmed in the seafloor sediment in these areas (Yamaguchi et al. 1995a, b, 2002; Kotani et al. 1998; Ishikawa et al. 2007; Yamamoto et al. 2009b), and it was concluded that this species has been completely established in the Seto Inland Sea and Mikawa Bay. Outbreaks of PSP were historically restricted to the Tohoku and Hokkaido areas but have recently been observed in the Seto Inland Sea, particularly in Osaka Bay (Table 3). The driver for this expanding distribution is the presence of cysts and/or temporary cysts of $A$. catenella (group I) that are simultaneously carried from the waters of northeastern Japan to the Seto Inland Sea when bivalve culture seedlings (mainly oysters) are transported (Nagai 2007). Microsatellite markers have been developed using population genetic methods and molecular techniques, confirming the spread of toxic A. catenella (group I) (Nagai 2007; Nagai et al. 2007). As a result, possible cases in which the distribution of HABs expands with the transfer of aquatic seedlings have been suggested (Nagai et al. 2007; Matsuyama et al. 2010).

The Great East Japan Earthquake, and the accompanying tsunami, struck the Pacific coast of Tohoku and Hokkaido on 11 March 2011. The tsunami caused significant seabed turbulence, and cysts of the toxic dinoflagellate A. catenella
Table 3 Cases of PSP in Japan. Data modified from Imai and Itakura (2007)

\begin{tabular}{|c|c|c|c|}
\hline Date & Locality (City/Town, Prefecture) & Poisoned shellfish & $\begin{array}{l}\text { Patients } \\
\text { (mortali- } \\
\text { ties) }\end{array}$ \\
\hline July 1947 & Toyohashi, Aichi & Manila clam & $12(1)$ \\
\hline May 1961 & Ohfunato, Iwate & Farrer's scallop & $20(1)$ \\
\hline February 1962 & Miyazu, Kyoto & Oyster (aquaculture) & $42(0)$ \\
\hline January 1979 & Senzaki, Yamaguchi & Oyster (aquaculture) & $16(0)$ \\
\hline April 1979 & Asahikawa, Hokkaido & Blue mussel & $3(1)$ \\
\hline May 1982 & Ohfunato, Iwate & Sea squirt & $2(0)$ \\
\hline June 1987 & Kagoshima, Kagoshima & Manila clam & $1(0)$ \\
\hline \multirow[t]{2}{*}{ April 1989} & \multirow[t]{2}{*}{ Ohfunato, Iwate } & Scallop & $5(0)$ \\
\hline & & Blue mussel & $1(0)$ \\
\hline July 1989 & Shimokita, Aomori & Blue mussel & $6(1)$ \\
\hline May 1991 & Nanae, Hokkaido & Scallop & $1(0)$ \\
\hline April 1996 & Nobeoka, Miyazaki & Blue mussel & $2(0)$ \\
\hline March 1997 & Tamanoura, Nagasaki & Oyster (nature) & $26(0)$ \\
\hline February 1998 & Yawatahama, Ehime & Oyster (nature) & $4(0)$ \\
\hline April 2008 & Kaizuka, Osaka & Blue mussel & $3(0)$ \\
\hline May 2013 & Osaka, Osaka & Blue mussel & $2(0)$ \\
\hline May 2015 & Tochigi & Scallop & $4(0)$ \\
\hline March 2016 & Hannan, Osaka & Manila clam & $2(0)$ \\
\hline \multirow[t]{4}{*}{ March 2016} & Sennan, Osaka & Manila clam & $1(0)$ \\
\hline & Sakai, Osaka & Blue mussel & $3(0)$ \\
\hline & Hyogo (Seto Inland Sea) & Blue mussel & $1(0)$ \\
\hline & Hyogo (Seto Inland Sea) & Japanese geoduck & $1(0)$ \\
\hline March 2019 & Misaki, Osaka & Blue mussel & $2(0)$ \\
\hline
\end{tabular}


(group I) were suspended in the water column from the bottom sediment (Kamiyama et al. 2014). After that, cysts tended to settle more slowly than sand grains due to their lower specific gravity, concentrating on the surface layer of seafloor sediment in Sendai (Kamiyama et al. 2014), Kesennuma (Ishikawa et al. 2015), and Funka Bays (Natsuike et al. 2014). As a result, large-scale blooms of A. catenella (group I) started to occur in Kesennuma Bay on the Pacific coast of the Tohoku region (Ishikawa et al. 2015). Despite the fact that shellfish toxification of PSP toxins had once been rare in Kesennuma Bay, contamination of scallops with PSP toxins has now become common (Tanabe and Kaga 2017).

The expansion of the scale of blooms due to A. catenella (group I) is noteworthy in Osaka Bay (Fig. 2), with an apparent increasing trend since 1994 (Yamamoto et al. 2017). A high-density red tide of 72,400 cells $\mathrm{mL}^{-1}$ occurred in April 2007 at the Sakai Dejima Fishing Port in Osaka Prefecture, and another of 14,000 cells $\mathrm{mL}^{-1}$ was confirmed in Yodo River (Yamamoto et al. 2009a, 2011, 2013). These events revealed that $A$. catenella (group I) not only causes toxification of bivalve mollusks by PSP toxins with low cell densities, but if conditions are suitable, this species can cause red tides and kill various forms of marine life (Yamamoto et al. 2009a). Until now, bivalve toxification was limited to marine species, but blooming in Yodo River was the first documented case to detect accumulation of PSP toxins in brackish water clams Corbicula japonica (Yamamoto et al. 2011). In the past, when eutrophication was prominent in Osaka Bay, diatoms were always predominant, while flagellates were relatively scarce due to lower growth rates. However, recently, it has been documented that diatoms can consume seawater nutrients, cease growth after nutrient depletion, and disappear from the water column. Theoretically, Alexandrium catenella (group I) can utilize the available nutrients after the disappearance and/or decrease of diatoms and thus form exceptionally high-density blooms, eventually leading to red tides (Yamamoto et al. 2017).

Mouse assays have been employed as the official method for monitoring toxin contamination of bivalves by toxic plankton (Iioka 2017; Suzuki 2017). However, since many countries consider the mouse assay to be a violation of animal welfare, instrumental analysis of toxin levels has gained support. According to a notification from the Ministry of Health, Labor, and Welfare, dated March 6, 2015, instrumental analyses have been adopted as the official method for measuring DSP toxins (okadaic acid and dinophysis toxins), with a regulated value of $0.16 \mathrm{mg}$ okadaic acid (OA) per kg of edible part of bivalves. Consequently, yessotoxin and pectenotoxin, previously detected by mouse assay, are excluded from instrumental analyses (Iioka 2017).

A major advancement in the field of DSP studies was made with the successful culturing and maintaining of the toxic dinoflagellate genus Dinophysis (Park et al. 2006; Nagai et al. 2008, 2020). Chloroplasts of the ciliate Mesodinium rubrum were found to be derived from cryptophytes by kleptoplasty (Gustafson et al. 2000), and it became possible to culture M. rubrum alongside the prey of cryptophytes as feed and the chloroplast source (Yih et al. 2004). The first culture was achieved for mixotrophic D. acuminata (Park et al., 2006), and subsequent successful cultures of important species including $D$. fortii, D. infundibulum, D. caudata, $D$. tripos, etc., and investigations on toxin production and chloroplast characteristics have been carried out (Kamiyama et al. 2010; Nishitani et al. 2010; Nagai et al. 2020).

The relationship between Dinophysis spp. and the DSP toxicity of bivalves displays a number of enigmas. In the coastal waters of western Japan, such as the Seto Inland Sea, DSP problems did not occur even when the causative species $D$. fortii was detected at sufficiently high densities (Imai and Itakura 2007; Nishitani et al. 2016). In Mutsu Bay in northern Japan, toxification of scallops was less likely when D. fortii populations increased in the surface and shallow waters, whereas an increase observed in the deeper layers near the sea bottom led to toxicity levels exceeding regulation levels (Nishitani et al. 2016). In Mutsu Bay, scallops reared in the upper layers are reported to be less toxic than those in the deep layers (Tanaka et al. 1985). Therefore, monitoring Dinophysis populations in deep waters is critical
Fig. 2 Annual changes in maximum cell density of toxic dinoflagellate Alexandrium catenella (group I; formerly A. tamarense) in Osaka Bay, eastern Seto Inland Sea, 1980-2020

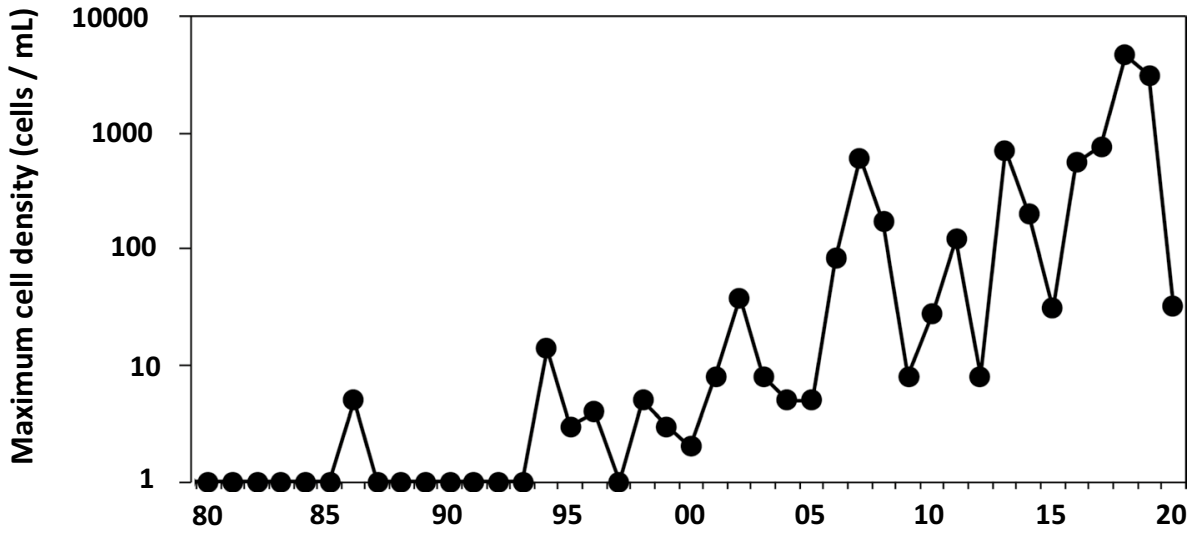


for predicting scallop toxification in aquaculture. The elucidation of the mechanism of toxification of scallops by deep populations of $D$. fortii is eagerly awaited from a practical point of view.

\section{Environmentally friendly strategies against HABs}

The occurrence of red tides and fishery damage has a long history. Mass mortality of farmed pearl oyster caused by K. mikimotoi was recorded in Gokasho and Ago Bays in Mie Prefecture in 1933 (Oda 1935). Since the mass mortality of cultured fish and bivalves caused by harmful red tides increased in scale and frequency in the 1960s with urbanization, various countermeasure techniques were investigated and proposed until the 1980s (Shirota 1989). However, regarding physicochemical countermeasures, few technologies have been applied except for clay spraying. This is because of no considerations regarding the scale or economic cost and the lack of careful attention to the environments (Imai 2017b).

Grazing of red tide plankton by zooplankton (copepods and protozoa) and bivalves has previously attracted significant attention and has been studied for the extermination of red tides; however, zooplankton tend to avoid grazing harmful plankton species (Uye and Takamatsu 1990; Mikhail 2007). Considering the abundance of copepods and calculated grazing rates, their capacity for removal of red tide plankton was estimated to be at most a few percent of the causative phytoplankton population per day, thus deemed impractical (Uye 1986). Heterotrophic dinoflagellates, such as the genera Gyrodinium and Polykrikos, appear and graze upon the raphidophytes Chattonella spp., and the dinoflagellate K. mikimotoi in coastal seas at the final stages of their blooms (Nakamura et al. 1992, 1996; Matsuyama et al. 1999). This has also been confirmed in laboratory experiments (Nakamura et al. 1992). However, cultivating and preparing large quantities of heterotrophic dinoflagellates to control red tides in the sea is also impractical.

Filter feeding of red tide phytoplankton by bivalves was once eagerly awaited in the pertinent aquaculture industries. In the northern part of Hiroshima Bay, the Seto Inland Sea, where oyster farming has been performed extensively, the corresponding amount of filter feeding of suspended matter (phytoplankton and detritus) by cultured oysters was estimated to be $26 \%$ of the amount of local primary production on the basis of average annual nitrogen balance (Songsangjinda et al. 2000). Bivalves also show selectivity for plankton as food (Baker et al. 1998). However, although oyster farming has some effect on thinning out phytoplankton communities, it is unlikely that the cultured oysters contribute to the prevention of red tide occurrences. Thus, the frequent occurrence of red tides in Hiroshima Bay suggests that aquacultures of bivalves are ineffective for prevention, and it was further concluded that controlling red tides through grazers is impractical (Imai 2010c).

All strategies for addressing harmful red tides must be practically feasible and environmentally friendly. Table 4 summarizes red tide countermeasures that have been evaluated as effective at the present or as promising in the future. Thus far, indirect strategies have been instrumental in reducing the incidence of red tides. In particular, legal regulations have contributed significantly to water quality improvements, especially in the Seto Inland Sea. With regards to aquaculture technologies, improvement of food quality has reduced water pollution during feeding. At present, stopfeeding (i.e., short-time starvation) is the measure that is most commonly employed to reduce fish mortality during red tides (Ohta 2018). Improving modeling accuracy for forecasting and monitoring red tide occurrences would also be promising for reducing fishery damage in the future (Onitsuka et al. 2016). Regarding direct countermeasures, clay spraying has been the most commonly employed tactic (Kagoshima Prefecture 1982, 2018; Kim 2006; Park et al. 2013). Recently, significant improvements in clay quality, such as an enhancement of the aggregated cohesive ability of red tide plankton, have enhanced its usefulness as an urgent countermeasure tactic (Murata 2017; Seger et al. 2017). Further, a dense seed bed of the toxic dinoflagellate A. catenella (group I) was identified in the inner part of Kesennuma Bay, Iwate Prefecture (Ishikawa et al. 2015), and the removal of bottom sediments containing dense cysts of HAB species located within the seed bed (Table 4) is thought to effectively reduce seed populations and prevent toxic blooms in small-scale embayments, such as Kesennuma Bay (Mine et al. 2015).

Biological controls using bacteria (Imai et al. 1993, 1995; Imai and Yamaguchi 2012; Imai 2015) and viruses (Tomaru et al. 2004, 2007; Nagasaki et al. 2006; Nagasaki 2008), or techniques exploiting the ecophysiological characteristics of red tide organisms (e.g., disturbance of thin-layer orientation in K. mikimotoi; Miyamura 2017) require further examination for practical use. Biological control methods are expected to be environmentally friendly and feasible.

The red tide countermeasures that are considered to be effective now or promising in the future are summarized in Fig. 3 in association with the stage transition of red tide occurrences. Monitoring is fundamental for enacting appropriate countermeasures before outbreaks, during the early stages and peak period, and until termination.

In the early stages of $K$. mikimotoi red tide initiation, thin-layer orientation has frequently been observed in subsurface layers with high cell densities (Aoki et al. 2017), and the physical disturbance of this thin layer has been proposed to be effective to prevent the development of red 
Table 4 Practical and promising countermeasures for HABs. Data modified from Imai (2017a)

Indirect methods

Legal regulation

Act on Special Measures Concerning Conservation of the Environment of the Seto Inland Sea, Act on Special Measures Concerning Restora-

tion of the Environment of the Ariake Sea and Yatsushiro Sea, Water Pollution Control Law, Marine Pollution Prevention Law, Regulation

Law of Agriculture Chemicals, Sustainable Aquaculture Production Assurance Act, etc.

Forecasting by monitoring

Regular monitoring, molecular monitoring

Improvement of prediction accuracy by data analysis and modeling

Fish culture technique

Improvement of bait (moist pellet), maintaining proper scale and density of fish, large-scale and deep pen cages

Emergency procedures

Feeding stop, transfer of net cages (horizontal and vertical)

Direct methods

Physicochemical methods

Clay spraying

Disturbance of thin-layer orientation of population (Karenia mikimotoi, etc.)

Removal of bottom sediments containing dense cysts of HAB species located in the seed bed

Biological control

Algicidal activity: viruses, algicidal bacteria, parasitic protists (dinoflagellates, etc.)

Competitive overwhelming: diatoms (diatom growth after germination of diatom resting stage cells in sediments lifted to the euphotic layer

with bottom perturbation by submarine tillage)

tides (Miyamura 2017). In the case of $H$. circularisquama red tides, treating frozen bottom sediments collected from red tide areas with algicidal viruses was demonstrated to be an effective preventive measure (Nakayama et al. 2020). Further, perturbation of the bottom sediment for utilizing diatom resting stage cells was proposed to prevent the occurrence of red tides due to harmful flagellates such as Chattonella spp. (results discussed below; Imai 2010b; Imai et al. 2017a). The restoration and creation of seaweed and seagrass beds could increase algicidal bacteria from their biofilm in surrounding areas, thereby mitigating HABs (Imai and Yamaguchi 2012; Imai 2015; Imai et al.
2016, 2017b; Inaba et al. 2017). If these strategies are implemented appropriately, they are anticipated to mitigate and significantly reduce the frequency and damage caused by HABs.

As promising and practical strategies against red tides, we introduce two biological methods below: The development of seaweed and seagrass beds (utilization of algicidal bacteria; Imai et al. 2002, 2016; Imai 2015; Inaba et al. 2017) and bottom sediment perturbation (utilization of the diatom resting stage cells in bottom sediments; Imai 2010b; Imai et al. 2017a).
Fig. 3 Possible and/or promising countermeasures against HABs at each stage. HA, harmful algae; DRSC, diatom resting stage cells. Data modified from Imai (2017b)

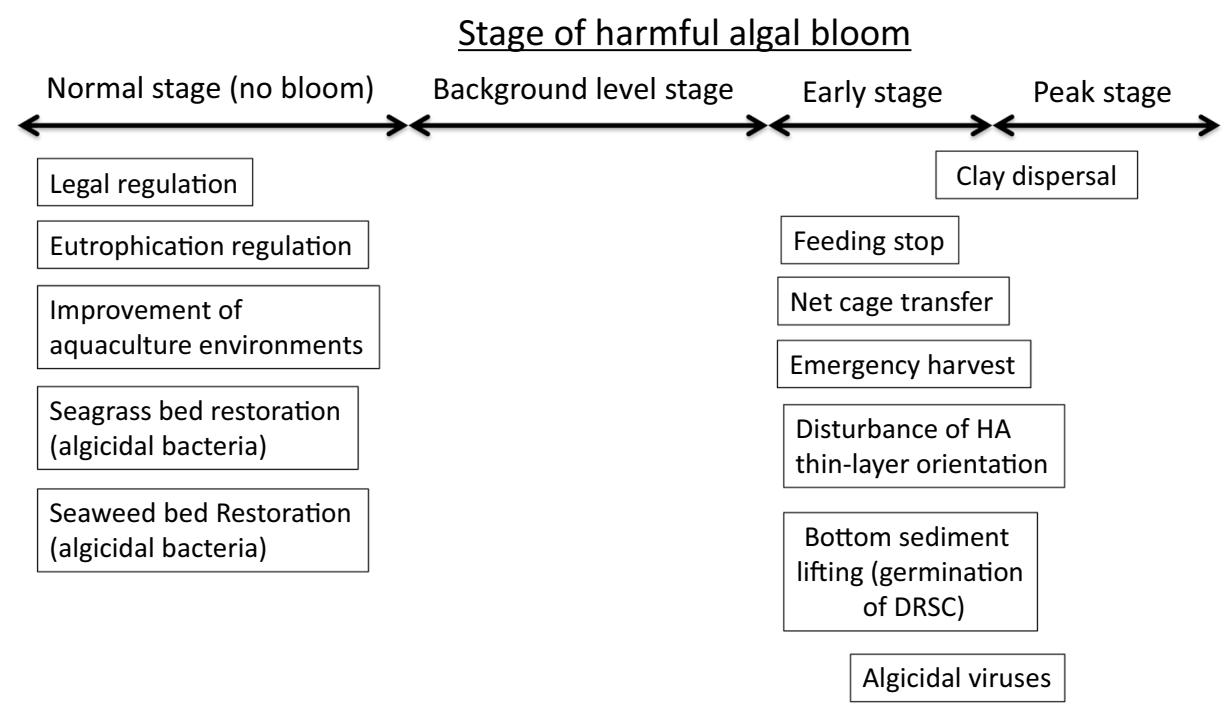

Harmful algae monitoring (prediction of occurrence and termination) 


\section{Algicidal and growth-inhibiting bacteria associated with seaweed and seagrass beds}

Algicidal bacteria can attack and kill microalgae, utilizing organic matter to proliferate (Imai 2011). Growth-inhibiting bacteria cause motility reduction and/or cell deformation of microalgae, ultimately leading to death (Inaba et al. 2014). Studies on the distribution of these bacteria have found that they commonly inhabit the coastal waters of Japan, and increase in abundance from peak to termination of red tides, playing a key role in red tide disintegration (Imai et al. 1998a, 2001). In fact, many strains of algicidal and growthinhibiting bacteria have been isolated from coastal seawaters in Japan and elsewhere around the world (Imai et al. 1993,
1995; Imai and Yoshinaga 2002; Mayali and Azam 2004; Inaba et al. 2014, 2017; Onishi et al. 2014, 2021).

As an example of the processes of algicidal and growthinhibiting bacteria, Fig. 4 shows various patterns of $C$. anti$q u a$. Since $C$. antiqua does not have a cell wall, its cells can be ruptured by algicidal activities. Various patterns of growth inhibition activities were observed for $C$. antiqua, with observed incidences of spheroidization, elongation, and irregular deformation of cell morphology (Inaba et al. 2014, 2019; Imai et al. 2016). In the case of the thecate dinoflagellates $A$. catenella (group I) and H. circularisquama, complete algal kill off is rare, and spherical cells (temporary cysts) are often formed as a result of growth-inhibition activities (Imai et al. 1998b, 2020; Nagasaki et al. 2000;
Fig. 4 Representative morphologies of Chattonella antiqua during co-culture experiments with algicidal and growthinhibiting bacteria. a Control: no addition of bacteria, $\mathbf{b}$ killed cells: algicidal activity, $\mathbf{c}$ round form: growth inhibition by no-motility inducing bacteria, $\mathbf{d}$ elongated type: growth inhibition by elongation inducing bacteria, and e deformed type: growth inhibition by deformation-inducing bacteria. Scale bar: $100 \mu \mathrm{m}$. Images acquired from Imai et al. (2016) (a) Control (no bacteria)

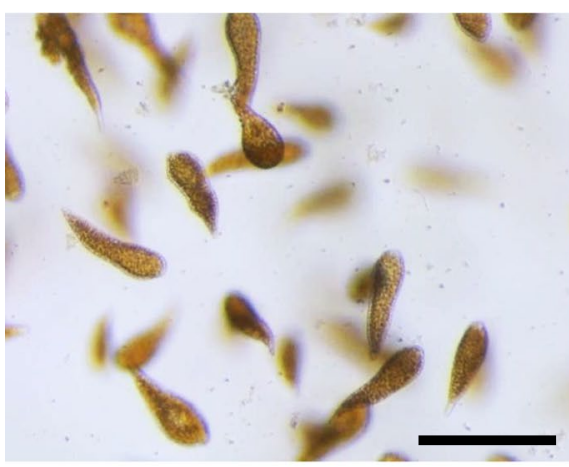

(c) Round form

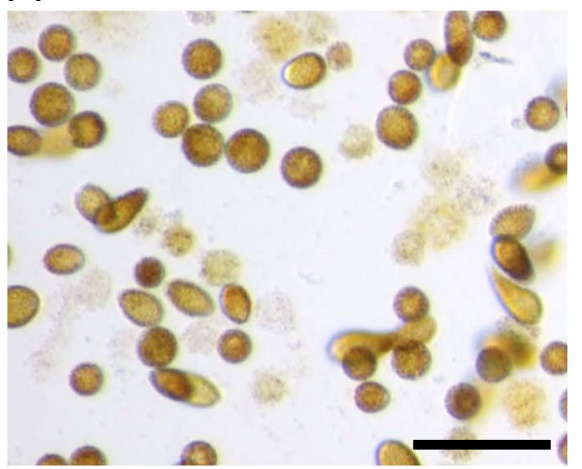

(e) Deformed type



(b) Killed cells

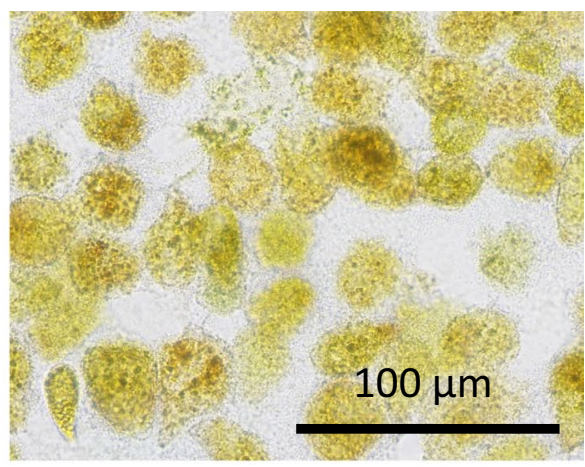

(d) Elongated type

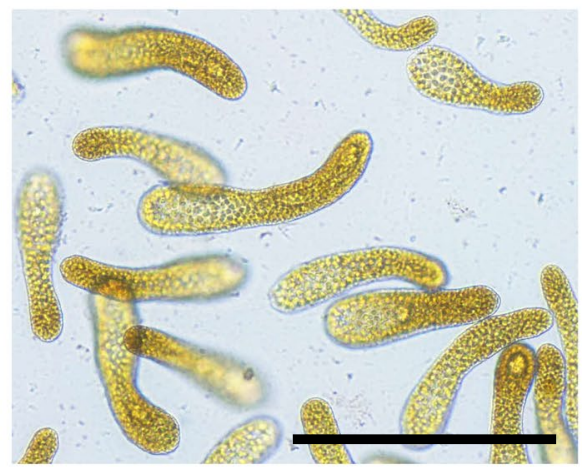


Onishi et al. 2014; Inaba et al. 2017). Most of the algicidal and growth-inhibiting bacteria belong to the Gram-negative $\alpha$-proteobacteria, $\gamma$-proteobacteria, and the phylum Bacteroides (Imai and Yoshinaga 2002; Mayali and Azam 2004; Imai et al. 2006b; Inaba et al. 2017, 2019; Onishi et al 2021).

The action of algicidal bacteria on HAB species can roughly be divided into two types: direct attack (mainly the phylum Bacteroides) and algicidal substance producers (Imai et al. 1993, 1995; Imai 1997; Meyer et al. 2017). When these bacteria start to exhibit algicidal activity, the first step is aggregation at the target algal cells (Imai et al. 1995). The involvement of quorum sensing has been suggested to control algicidal activities, such as producing algicidal substances (Fuqua et al. 1994; Nakashima et al. 2006; Kodama et al. 2017). As the algicidal substances, serine protease (Lee et al. 2000), prodigiosin (Nakashima et al. 2006), isatin (Sakata et al. 2011), and questiomycins (Umetsu et al. 2019), etc., have been reported.

Ecological studies on the relationships between algicidal bacteria and red tides have been carried out in coastal seas. In one such study of a small red tide of Chattonella in Harima-Nada, the algicidal bacterium Cytophaga sp. J18/M01 increased immediately after the bloom peak, as revealed by the indirect fluorescent antibody method using an antibody that specifically detects this bacterium (Imai et al. 2001). It was also observed that the number of total bacteria (direct counts) increased rapidly immediately after a Chattonella red tide (Imai 2013). In H. akashiwo red tides, algicidal bacteria also increased after the bloom peak in the coastal waters of Hiroshima Bay, and a predator-prey relationship of abundance was observed (Imai et al. 1998a; Kim et al. 1998; Yoshinaga et al. 1998). Similar relationships were also observed in the South Carolina brackish detention ponds in the USA (Liu et al. 2008). Furthermore, it was reported that a greater proportion of algicidal bacteria were attached to particles such as detritus, than free-living bacteria (Park et al. 2010; Inaba et al. 2014), indicating that colony formation on particles is advantageous for these bacteria to express growth-limiting activities controlled by quorum sensing. Increased numbers of algicidal and growthinhibiting bacteria following an increase in red tide microalgae were observed to reduce algal numbers rapidly, together with heterotrophic bacteria due to feeding by heterotrophic nanoflagellates (Inaba et al. 2019). The influence of these temporarily predominant bacteria on the environment is thought to be small, making them a more environmentally friendly strategy for controlling HABs.

This research field was broadened to include seaweed beds for surveying algicidal bacteria. At one seaweed bed in Obama Bay, Fukui Prefecture, algicidal bacteria against the red tide raphidophytes Chattonella spp. (C. antiqua, C. marina, and C. ovata), H. akashiwo, and Fibrocapsa japonica were found at high densities despite the absence of these red tide raphidophytes (Imai and Yoshinaga 2002). The distribution of algicidal bacteria was investigated by targeting the raphidophytes $C$. antiqua, C. marina, $C$. ovata, $H$. akashiwo, and $F$. japonica, and the dinoflagellates $M$. polykrikoides and K. mikimotoi in a natural seaweed bed in Misaki Park, Osaka Prefecture (Imai et al. 2002). Enormous densities of algicidal bacteria were found to inhabit the surface of the green alga Ulva pertusa, the red alga Gelidium sp., and the brown algae Sargassum thunbergii and S. muticum (Imai et al. 2002). The densities of algicidal bacteria were as high as $10^{5}-10^{6} / \mathrm{g}$ of wet weight seaweed. Among the tested harmful algae, the dinoflagellate K. mikimotoi and the raphidophytes $H$. akashiwo and $F$. japonica were very effectively killed by algicidal bacteria isolated from the seaweed bed. Major isolated strains of algicidal bacteria from seaweed beds belonged to $\alpha$-proteobacteria, $\gamma$-proteobacteria, and the phylum Bacteroides, similar to the results obtained in red tide areas (Imai and Yoshinaga 2002; Imai et al. 2006b). A large number of algicidal bacteria were found to attach to the surface of Ulva pertusa in polyculture cages of seaweed and fish (Imai et al. 2012), ultimately leading to the successful introduction of $U$. pertusa beds using mobile floating cages to harbor bacteria that inhibit several HAB species (Inaba et al. 2020).

As the next step of the investigation, the seasonal distribution of algicidal bacteria was measured in a seagrass (Zostera marina) bed in Hannan, Osaka Prefecture, Japan. From June to October 2006, monthly samples were collected from the seagrass bed $\left(\sim 2000 \mathrm{~m}^{2}\right)$, which was restored naturally near Sennan-Sato-Umi Park (Imai et al. 2009, 2016). A large number of bacteria exhibiting algicidal activity against five species of red tide plankton were confirmed to inhabit the leaf surface of Z. marina at densities up to $6.4 \times 10^{7}$ (average of $\sim 10^{7}$ ) colony-forming units (CFU)/g (wet weight; Fig. 5). Calculating the densities of algicidal bacteria that kill at least one species of red tide microalgae, high densities of algicidal bacteria $\left(1 \times 10^{7}-9 \times 10^{7} \mathrm{CFU}\right)$ were found on $1 \mathrm{~g}$ of wet weight leaves of $Z$. marina. Algicidal bacteria were also detected in seawater from the seagrass bed at densities of $10^{3}-10^{4} \mathrm{CFU} / \mathrm{mL}$, and algicidal bacteria density in seawater was highest in the seagrass bed and lowest at the sandy beach. Cell densities of phytoplankton in seawater within the seagrass field were markedly lower than those in the offshore area of Osaka Bay (Imai et al. 2016), and similar decreased densities of phytoplankton have been observed in seagrass beds and surrounding waters elsewhere (Lee et al. 2006; Jacobs-Palmer et al. 2020).

The distribution of algicidal and growth-inhibiting bacteria against $H$. akashiwo and $A$. catenella (group I) was investigated by collecting seagrasses (Z. marina and Z. japonica), seaweed (U. lactuca), and seawater samples from various locations in Puget Sound on the west coast of the USA (Inaba et al. 2017). The densities of effective (algicidal and 


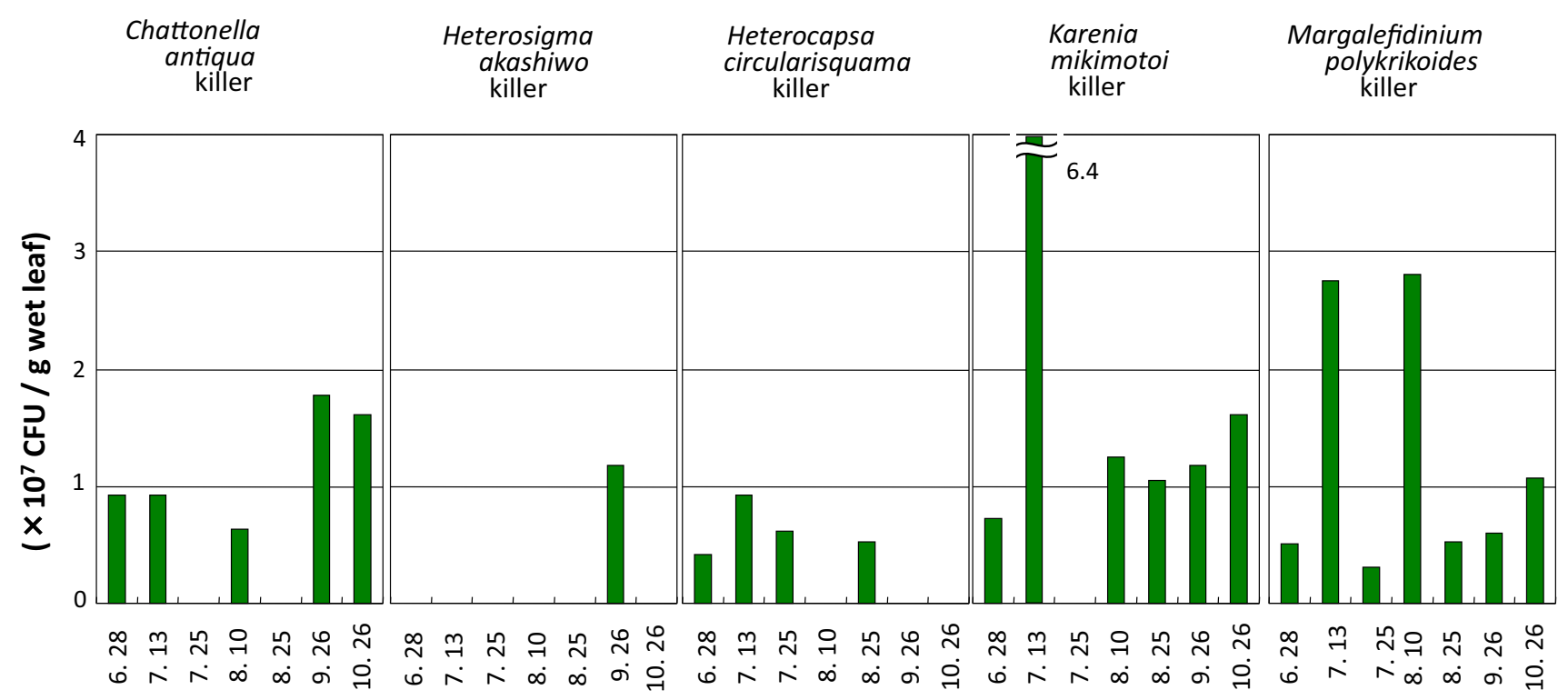

Fig. 5 Seasonal changes in densities of algicidal bacteria against five species of red tide plankton inhabiting the biofilm on the surface of seagrass Zostera marina. Seagrass samples were collected from the

growth-inhibiting) bacteria were found to reach a maximum of $10^{8}$ cells/g (wet weight) on Z. marina, similar to those observed in Osaka Bay. Additionally, the obtained effective bacteria also belonged to $\alpha$-proteobacteria, $\gamma$-proteobacteria, and the phylum Bacteroides in Puget Sound as well. Sakami et al. (2017) investigated the distribution of algicidal bacteria of three Alteromonas strains (S, K, D) in seagrass beds and external seawaters of the Seto Inland Sea. The analyzed Alteromonas strains were found more abundantly on the $Z$. marina leaves and in the seawater within the seagrass bed, as compared with the external seawater. Seagrass beds are thus presumed to be the source of these algicidal bacteria (Sakami et al. 2017). The influence of algicidal bacteria in a seagrass (Z. marina) bed and the capability of $C$. antiqua to control blooms were examined in a laboratory microcosm experiment (Inaba et al. 2019), revealing that bacterial communities in seawater collected from the seagrass bed and Z. marina biofilm suppressed artificial Chattonella blooms in the presence of their natural competitors (heterotrophic bacteria) and predators (heterotrophic nanoflagellates).

The distribution of algicidal bacteria in coastal waters is summarized in Table 5, revealing that seaweed and seagrass beds are hotspots of bacteria capable of killing and/or inhibiting the growth of harmful algae. It is further assumed that these bacteria are continuously supplied from seaweed and seagrass beds to the surrounding waters, thus restoration and creation of seaweed and seagrass beds could be a practical and environmentally friendly measure to prevent HABs. Seaweeds and seagrasses could be beneficial not only by harboring these bacteria but also through water quality restoration coast of Misaki Town, Osaka Prefecture, in 2006. Data partly modified from Imai et al. (2016)

via the uptake of excess nutrients, releasing allelochemicals that negatively affect the growth of HAB species, and some algal species are of commercial importance. An example application is the mixed aquaculture of fish and seaweed discussed above (Fig. 6). In this regard, applying the recently revealed ability of seaweed and seagrass beds to suppress HABs would be an ideal system from the viewpoint of bioremediation, as the habitat of these bacteria is prepared by the seaweeds and seagrasses (biostimulation), and proliferating bacteria are continuously supplied from their surfaces to the surrounding seawater (bioaugmentation). Probably the most significant advantage is that the costs of maintaining seaweed and seagrass beds are negligible.

\section{Utilization of diatoms}

It is empirically well known that diatoms are scarce in the water column when red tides occur due to harmful flagellates such as Chattonella spp., H. akashiwo, and K. mikimotoi (Itakura et al. 1996; Onitsuka et al. 2011; Shikata et al. 2011; Imai 2012; Nishi et al. 2012); however, many diatom resting stage cells are deposited on the bottom sediments of coastal seas (Imai et al. 1990; Itakura et al. 1997, 1999), and require light for germination and revival (Imai et al. 1996; Itakura 2000). Therefore, if the diatom resting stage cells in sediments are suspended from the seafloor into the water column of the euphotic layer, it is presumed that the vegetative cells of diatoms, which are generated through germination and rejuvenation from the resting stage cells, can consume nutrients in the water, proliferate, and overwhelm 
Table 5 Summary of published studies on algicidal or growth-inhibiting bacteria targeting HAB species investigated in seaweed and seagrass beds. Data modified from Inaba et al. (2017)

\begin{tabular}{|c|c|c|c|c|c|c|c|}
\hline Sampling site & Year & Source & $\begin{array}{l}\text { Target HAB } \\
\text { species }\end{array}$ & $\begin{array}{l}\text { Maximum } \\
\text { density of } A B \\
\text { and GIB }\end{array}$ & Method & Remark & Ref. \\
\hline \multirow[t]{9}{*}{$\begin{array}{l}\text { Osaka Bay, Seto } \\
\text { Inland Sea }\end{array}$} & \multirow[t]{9}{*}{1999} & \multirow[t]{3}{*}{ Ulva sp. } & $\begin{array}{c}\text { Heterosigma } \\
\text { akashiwo }\end{array}$ & $1.4 \times 10^{3} \mathrm{MPN} / \mathrm{g}$ & MPN & \multirow[t]{3}{*}{ Green alga } & \multirow[t]{9}{*}{ Imai et al. (2002) } \\
\hline & & & $\begin{array}{l}\text { Fibrocapsa } \\
\text { japonica }\end{array}$ & $1.2 \times 10^{4} \mathrm{MPN} / \mathrm{g}$ & MPN & & \\
\hline & & & $\begin{array}{l}\text { Karenia miki- } \\
\quad \text { motoi }\end{array}$ & $7.0 \times 10^{4} \mathrm{MPN} / \mathrm{g}$ & MPN & & \\
\hline & & \multirow[t]{3}{*}{ Gelidium sp. } & H. akashiwo & $2.6 \times 10^{5} \mathrm{MPN} / \mathrm{g}$ & MPN & \multirow[t]{3}{*}{ Red alga } & \\
\hline & & & F. japonica & $1.3 \times 10^{6} \mathrm{MPN} / \mathrm{g}$ & MPN & & \\
\hline & & & K. mikimotoi & $4.9 \times 10^{5} \mathrm{MPN} / \mathrm{g}$ & MPN & & \\
\hline & & \multirow[t]{3}{*}{ Seawater } & H. akashiwo & $\begin{array}{l}1.6 \times 10^{2} \mathrm{MPN} / \\
\mathrm{mL}\end{array}$ & MPN & \multirow[t]{3}{*}{ Seaweed bed } & \\
\hline & & & F. japonica & $\begin{array}{l}4.3 \times 10^{2} \mathrm{MPN} / \\
\mathrm{mL}\end{array}$ & MPN & & \\
\hline & & & K. mikimotoi & $\begin{array}{l}4.3 \times 10^{3} \mathrm{MPN} / \\
\mathrm{mL}\end{array}$ & MPN & & \\
\hline \multirow{13}{*}{$\begin{array}{l}\text { Shimo-Haya } \\
\text { Bay, Wakay- } \\
\text { ama }\end{array}$} & \multirow[t]{8}{*}{ 2002-2003 } & \multirow[t]{4}{*}{ Seawater } & H. akashiwo & $\begin{array}{l}2.0 \times 10^{2} \mathrm{MPM} / \\
\mathrm{mL}\end{array}$ & MPN & \multirow{4}{*}{$\begin{array}{l}\text { Aquaculture } \\
\text { pond with } \\
\text { Ulva pertusa }\end{array}$} & \multirow[t]{13}{*}{ Imai et al. (2012) } \\
\hline & & & $\begin{array}{l}\text { Chattonella } \\
\text { antiqua }\end{array}$ & $\begin{array}{l}1.0 \times 10^{2} \mathrm{MPN} / \\
\mathrm{mL}\end{array}$ & MPN & & \\
\hline & & & F. japonica & $\begin{array}{l}1.4 \times 10^{2} \mathrm{MPN} / \\
\mathrm{mL}\end{array}$ & MPN & & \\
\hline & & & K. mikimotoi & $\begin{array}{l}2.2 \times 10^{4} \mathrm{MPN} / \\
\mathrm{mL}\end{array}$ & MPN & & \\
\hline & & \multirow[t]{4}{*}{ Ulva pertusa } & H. akashiwo & $2.0 \times 10^{2} \mathrm{MPN} / \mathrm{g}$ & MPN & \multirow{4}{*}{$\begin{array}{l}\text { Aquaculture } \\
\text { pond with } \\
\text { Ulva pertusa }\end{array}$} & \\
\hline & & & C. antiqua & $8.0 \times 10^{2} \mathrm{MPN} / \mathrm{g}$ & MPN & & \\
\hline & & & F. japonica & $1.9 \times 10^{5} \mathrm{MPN} / \mathrm{g}$ & MPN & & \\
\hline & & & K. mikimotoi & $1.1 \times 10^{6} \mathrm{MPN} / \mathrm{g}$ & MPN & & \\
\hline & \multirow[t]{5}{*}{2003} & \multirow[t]{5}{*}{ Ulva pertusa } & H. akashiwo & $4.7 \times 10^{4} \mathrm{CFU} / \mathrm{g}$ & \multirow{5}{*}{$\begin{array}{l}\text { Bacterial } \\
\text { isolation and } \\
\text { co-culture }\end{array}$} & \multirow{5}{*}{$\begin{array}{l}\text { Aquaculture } \\
\text { pond with } \\
\text { Ulva pertusa }\end{array}$} & \\
\hline & & & C. antiqua & $9.4 \times 10^{4} \mathrm{CFU} / \mathrm{g}$ & & & \\
\hline & & & F. japonica & $2.3 \times 10^{5} \mathrm{CFU} / \mathrm{g}$ & & & \\
\hline & & & K. mikimotoi & $8.0 \times 10^{5} \mathrm{CFU} / \mathrm{g}$ & & & \\
\hline & & & $\begin{array}{l}\text { Heterocapsa cir- } \\
\text { cularisquama }\end{array}$ & $1.9 \times 10^{5} \mathrm{CFU} / \mathrm{g}$ & & & \\
\hline \multirow[t]{10}{*}{$\begin{array}{l}\text { Osaka Bay, Seto } \\
\text { Inland Sea }\end{array}$} & \multirow[t]{10}{*}{2006} & \multirow[t]{5}{*}{ Seawater } & H. akashiwo & $\begin{array}{l}2.4 \times 10^{3} \mathrm{CFU} / \\
\mathrm{mL}\end{array}$ & \multirow{5}{*}{$\begin{array}{l}\text { Bacterial } \\
\text { isolation and } \\
\text { co-culture }\end{array}$} & \multirow[t]{5}{*}{$\begin{array}{l}\text { Zostera marina } \\
\text { bed }\end{array}$} & \multirow[t]{10}{*}{ Imai et al. (2016) } \\
\hline & & & C. antiqua & $\begin{array}{l}4.8 \times 10^{3} \mathrm{CFU} / \\
\mathrm{mL}\end{array}$ & & & \\
\hline & & & K. mikimotoi & $\begin{array}{l}2.4 \times 10^{3} \mathrm{CFU} / \\
\mathrm{mL}\end{array}$ & & & \\
\hline & & & $\begin{array}{l}\text { H. circularis- } \\
\text { quama }\end{array}$ & $\begin{array}{l}1.8 \times 10^{3} \mathrm{CFU} / \\
\mathrm{mL}\end{array}$ & & & \\
\hline & & & $\begin{array}{c}\text { Margalefidinium } \\
\text { polykrikoides }\end{array}$ & $\begin{array}{l}2.3 \times 10^{3} \mathrm{CFU} / \\
\mathrm{mL}\end{array}$ & & & \\
\hline & & \multirow[t]{5}{*}{ Zostera marina } & H. akashiwo & $1.2 \times 10^{7} \mathrm{CFU} / \mathrm{g}$ & \multirow{5}{*}{$\begin{array}{l}\text { Bacterial } \\
\text { isolation and } \\
\text { co-culture }\end{array}$} & \multirow[t]{5}{*}{ Seagrass } & \\
\hline & & & C. antiqua & $1.8 \times 10^{7} \mathrm{CFU} / \mathrm{g}$ & & & \\
\hline & & & K. mikimotoi & $6.4 \times 10^{7} \mathrm{CFU} / \mathrm{g}$ & & & \\
\hline & & & $\begin{array}{l}\text { H. circularis- } \\
\text { quama }\end{array}$ & $9.2 \times 10^{6} \mathrm{CFU} / \mathrm{g}$ & & & \\
\hline & & & M. polykrikoides & $2.8 \times 10^{7} \mathrm{CFU} / \mathrm{g}$ & & & \\
\hline
\end{tabular}


Table 5 (continued)

\begin{tabular}{|c|c|c|c|c|c|c|c|}
\hline Sampling site & Year & Source & $\begin{array}{l}\text { Target HAB } \\
\text { species }\end{array}$ & $\begin{array}{l}\text { Maximum } \\
\text { density of } \mathrm{AB} \\
\text { and GIB }\end{array}$ & Method & Remark & Ref. \\
\hline \multirow[t]{8}{*}{$\begin{array}{l}\text { Puget Sound, } \\
\text { USA }\end{array}$} & \multirow[t]{8}{*}{ 2012-2013 } & Seawater & H. akashiwo & $\begin{array}{l}1.8 \times 10^{3} \mathrm{CFU} / \\
\mathrm{mL}\end{array}$ & \multirow{8}{*}{$\begin{array}{l}\text { Bacterial } \\
\text { isolation and } \\
\text { co-culture }\end{array}$} & Dumas Bay & \multirow[t]{8}{*}{ Inaba et al. (2017) } \\
\hline & & & $\begin{array}{c}\text { Alexandrium } \\
\text { catenella } \\
\text { (Group I) }\end{array}$ & $\begin{array}{l}4.1 \times 10^{3} \mathrm{CFU} / \\
\mathrm{mL}\end{array}$ & & Holmes Harbor & \\
\hline & & \multirow[t]{2}{*}{ Zostera marina } & H. akashiwo & $1.6 \times 10^{8} \mathrm{CFU} / \mathrm{g}$ & & $\begin{array}{l}\text { Pier at Friday } \\
\text { Harbor Labo- } \\
\text { ratory }\end{array}$ & \\
\hline & & & $\begin{array}{c}\text { A. catenella } \\
\text { (Group I) }\end{array}$ & $7.5 \times 10^{7} \mathrm{CFU} / \mathrm{g}$ & & $\begin{array}{l}\text { Central Padilla } \\
\text { Bay }\end{array}$ & \\
\hline & & \multirow[t]{2}{*}{ Zostera japonica } & H. akashiwo & $2.8 \times 10^{8} \mathrm{CFU} / \mathrm{g}$ & & $\begin{array}{l}\text { Central Padilla } \\
\text { Bay }\end{array}$ & \\
\hline & & & $\begin{array}{l}\text { A. catenella } \\
\text { (group I) }\end{array}$ & $1.8 \times 10^{8} \mathrm{CFU} / \mathrm{g}$ & & $\begin{array}{l}\text { Central Padilla } \\
\text { Bay }\end{array}$ & \\
\hline & & \multirow[t]{2}{*}{ Ulva lactuca } & H. akashiwo & $1.3 \times 10^{8} \mathrm{CFU} / \mathrm{g}$ & & $\begin{array}{l}\text { Shallow Bay, } \\
\text { Sucia }\end{array}$ & \\
\hline & & & $\begin{array}{l}\text { A. catenella } \\
\text { (group I) }\end{array}$ & $6.9 \times 10^{5} \mathrm{CFU} / \mathrm{g}$ & & Cattle Point & \\
\hline \multirow[t]{5}{*}{$\begin{array}{l}\text { Shinori Coast, } \\
\text { Hokkaido }\end{array}$} & \multirow[t]{5}{*}{2011} & Seawater & $\begin{array}{l}\text { A. catenella } \\
\text { (group I) }\end{array}$ & $\begin{array}{l}2.5 \times 10^{3} \mathrm{CFU} / \\
\mathrm{mL}\end{array}$ & \multirow{5}{*}{$\begin{array}{l}\text { Bacterial } \\
\text { isolation and } \\
\text { co-culture }\end{array}$} & Seaweed bed & \multirow[t]{5}{*}{ Imai et al. (2020) } \\
\hline & & $\begin{array}{r}\text { Laminaria } \\
\text { japonica }\end{array}$ & $\begin{array}{l}\text { A. catenella } \\
\text { (group I) }\end{array}$ & $3.7 \times 10^{5} \mathrm{CFU} / \mathrm{g}$ & & Brown alga & \\
\hline & & $\begin{array}{l}\text { Sargassum } \\
\text { thunbergii }\end{array}$ & $\begin{array}{l}\text { A. catenella } \\
\text { (group I) }\end{array}$ & $3.7 \times 10^{5} \mathrm{CFU} / \mathrm{g}$ & & Brown alga & \\
\hline & & $\begin{array}{l}\text { Corallina pilu- } \\
\text { lifera }\end{array}$ & $\begin{array}{l}\text { A. catenella } \\
\text { (group I) }\end{array}$ & $1.1 \times 10^{6} \mathrm{CFU} / \mathrm{g}$ & & Red alga & \\
\hline & & Ulva pertusa & $\begin{array}{l}\text { A. catenella } \\
\text { (group I) }\end{array}$ & $3.7 \times 10^{5} \mathrm{CFU} / \mathrm{g}$ & & Green alga & \\
\hline \multirow{2}{*}{$\begin{array}{l}\text { Akkeshi-ko, } \\
\text { Akkeshi Bay, } \\
\text { Hokkaido }\end{array}$} & \multirow[t]{2}{*}{2011} & Seawater & $\begin{array}{l}\text { A. catenella } \\
\text { (group I) }\end{array}$ & $\begin{array}{l}1.1 \times 10^{3} \mathrm{CFU} / \\
\mathrm{mL}\end{array}$ & \multirow{2}{*}{$\begin{array}{l}\text { Bacterial } \\
\text { isolation and } \\
\text { co-culture }\end{array}$} & Akkeshi Bay & \multirow[t]{2}{*}{$\begin{array}{l}\text { Onishi et al. } \\
\text { (2021) }\end{array}$} \\
\hline & & Zostera marina & $\begin{array}{l}\text { A. catenella } \\
\text { (group I) }\end{array}$ & $4.7 \times 10^{6} \mathrm{CFU} / \mathrm{g}$ & & $\begin{array}{l}\text { Zostera marina } \\
\text { bed }\end{array}$ & \\
\hline
\end{tabular}

$H A B$ harmful algal bloom, $A B$ algicidal bacteria, $G I B$ growth-inhibiting bacteria, $M P N$ most probable number, $C F U$ colony forming unit

harmful flagellates. In fact, Takahashi et al. (1977) reported that, after a vertical mixing event in coastal areas due to strong winds, nutrients and the seed stock of phytoplankton in bottom sediments primarily composed of diatoms were lifted to the euphotic layer; consequently, diatom blooms occurred and lasted for several days to weeks from spring to summer. Bottom sediment perturbation can thus be utilized as a practical method to artificially induce such a phenomenon (Fig. 7; Imai 2010b). The disturbance of the sea, which is usually caused by natural processes such as typhoons, can be artificially induced by bottom sediment perturbation under calm weather conditions. Bottom sediment perturbation is performed by submarine tillage, originally a common technique in Japan for improving deteriorated bottom sediment environments in the coastal seas (Nakanishi 2002).

There is a lack of knowledge about the effects of bottom sediment perturbation by artificial submarine tillage on phytoplankton communities in seawater; and to the best of the authors' knowledge, Imai et al. (2017a) is the only study to date to have examined such effects. Since the diatom resting stage cells are suspended in the water column, the resulting diatoms that germinate from the resting stage cells in the euphotic layer would join the phytoplankton community. Thus, it can be presumed that the quality (i.e., composition) and quantity (i.e., density) of the phytoplankton community 




Fig. 6 Schematic representation of polycultured fish with seaweed, and prevention of harmful red tides by the release of algicidal bacteria from the seaweed. Algicidal bacteria derived from seaweeds

are greatly affected and induced to diatom-predominant communities.

The following is a description of the first case report of successful suppression of Chattonella populations by bottom sediment perturbation in the Seto Inland Sea (Imai et al. 2017a). Bottom sediment perturbation by submarine tillage was carried out on 7 and 8 July 2016 in the Tomono-Ura area of the Seto Inland Sea, Fukuyama City, Hiroshima Prefecture, where Chattonella red tides frequently occur. Two sites, Stn. A in the nontillage area and Stn. B in the sediment perturbation area, were set up to monitor changes in environmental factors and phytoplankton communities. Diatom resting stage cells were present in the bottom sediments at densities of $1.2 \times 10^{5}$ and $1.7 \times 10^{5} / \mathrm{g}$ (wet sediment) for Stn. $\mathrm{A}$ and $\mathrm{B}$, respectively. During the investigation period, the water temperature and salinity tended to show the same pattern at both sites, and the effects of perturbations were negligible. The dynamics of phytoplankton are shown in Fig. 8. In the perturbation area of Stn. B, diatoms increased from 48 to 1383 cells $/ \mathrm{mL}$, and Chattonella spp. varied between 0 and 34 cells $/ \mathrm{mL}$. Diatoms increased significantly on day 0 (immediately following sediment perturbation, 8 July) at Stn. B compared with day -1 (i.e., the day immediately prior to perturbation, 7 July). By day 7 , diatoms in the surface layer increased to 30 times the density levels of day -1 . Additionally, Chattonella spp. first existed in the mid- and bottom depths at a density of 34 cells $/ \mathrm{mL}$ on day -1 and, following perturbation, declined without proliferating as a whole after 7 days. Overall, perturbation by submarine tillage resulted in the predominance of diatoms and substantially suppressed the growth of Chattonella spp. At Stn. A (nonperturbation

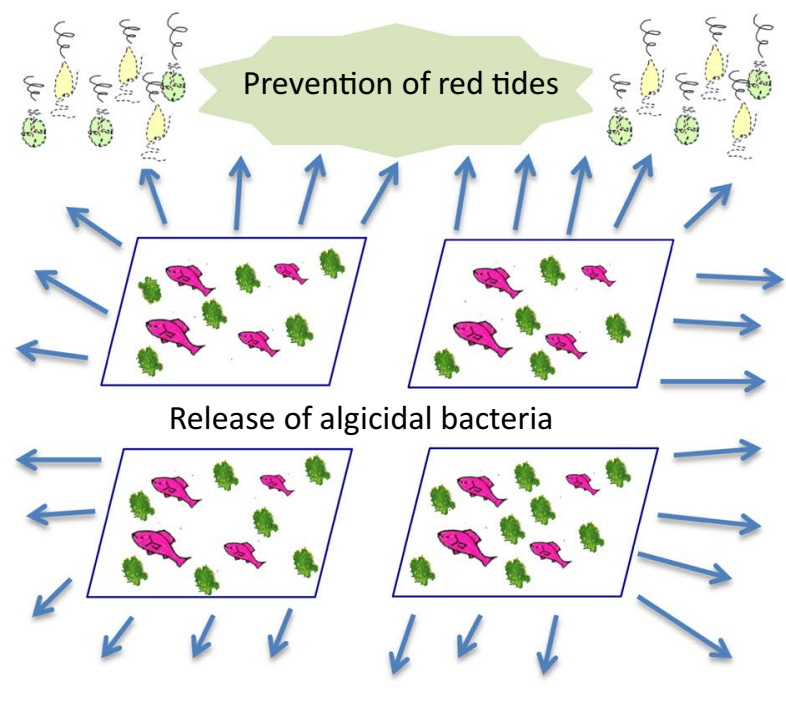

are widely supplied to surrounding waters and expected to suppress phytoplankton growth and thereby the occurrence of red tides. Data modified from Imai et al. (2002)

area), diatoms showed cell densities of $61-376$ cells $/ \mathrm{mL}$, and Chattonella spp. cell densities of 0-30 cells $/ \mathrm{mL}$. Since Stn. A was relatively near Stn. B (i.e., the sediment perturbation area), the water mass of the perturbation area probably influenced Stn. A as well. The bottom sediment perturbation was performed again in August 2016, and twice in the summer of 2017, and in both years, the increase in Chattonella cells was prevented after each of the sediment perturbation trials similarly as shown in Fig. 8.

Chattonella spp. are repelled by copepods (Uye and Takamatsu, 1990). When diatoms are predominant, zooplankton such as copepods actively graze upon diatoms, and furthermore, the food webs would be driven smoothly, and the situation would be favorable for production of planktivorous fishes such as anchovy, sardine, and horse mackerel. In general, diatoms are less abundant during the period from the time after spring bloom until autumn in the coastal seas of temperate to Arctic areas, leading to frequent occurrences of harmful flagellate blooms in the summer. Sediment perturbation could potentially prevent HABs after the spring bloom, activating food webs, and increasing the total stock and production of fish and other marine life at higher trophic levels.

Competitions of Chattonella spp. and diatoms produced by germination and rejuvenation of resting stage cells suspended in seawater were studied using bottle incubation experiments (Imai et al. 2017a). Seawater samples containing suspended sediments were collected from the middle layer ( $2 \mathrm{~m}$ depth) at Stn. B in the bottom sediment perturbation area immediately following the implementation. Then, four experimental plot bottles (a-d) were set by combining 
Fig. 7 Schematic representation of sediment perturbation as a control strategy for Chattonella red tides in coastal seas. Bottom sediments containing numerous diatom resting stage cells are lifted to euphotic layers by bottom sediment tillage with a submarine tractor or trawling fishing gears. Germinated and/ or rejuvenated diatom vegetative cells multiply vigorously and become dominant in the water column, resulting in the decay of Chattonella populations by virtue of nutrient exhaustion. Data partly modified from Imai et al. (2017a)

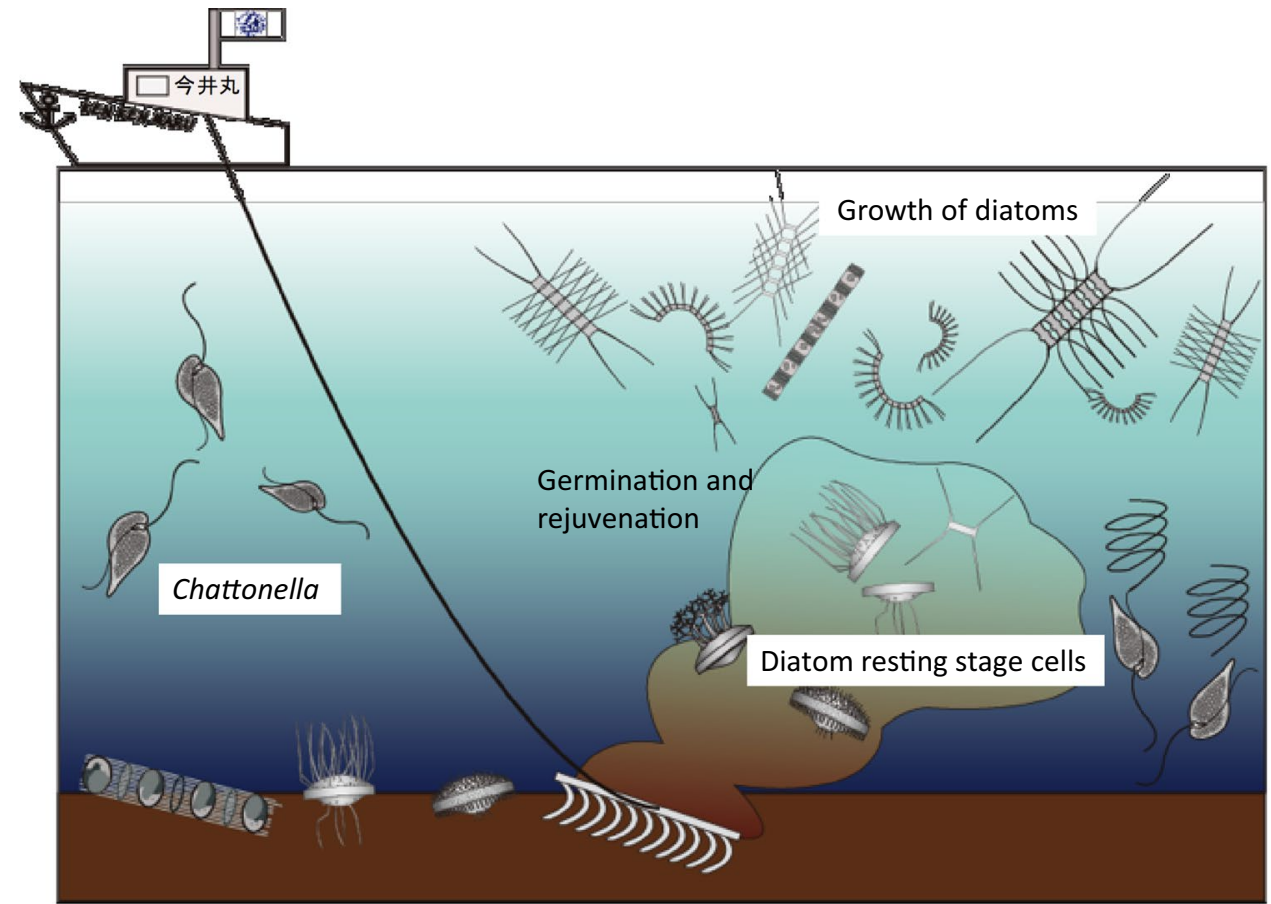

additional concentrations of $C$. antiqua and modified SWM-3 medium with 1/100 strength (Table 6). Experimental conditions were temperature of $25^{\circ} \mathrm{C}$, light intensity of $50 \mu \mathrm{mol}$ photons $/ \mathrm{m}^{2} / \mathrm{sec}$, and photoperiod of $14 \mathrm{~h}$ light: $10 \mathrm{~h}$ dark. Nutrient concentrations in the bottles decreased sharply from days 2 to 4 . Fluctuations in phytoplankton for each experimental bottle are shown in Fig. 9. Chattonella spp. began to decrease shortly after the start of the experiment, and disappeared by the 14th day. In particular, Chattonella spp. disappeared fastest in experimental bottles (a) and (b), containing only the cells of Chattonella spp. in the original seawater, at a lower density. Additionally, diatoms grew and reached a density of approximately $10^{4}$ cells $/ \mathrm{mL}$, overwhelming Chattonella spp. Another bottle experiment was carried out with the addition of HAB species ( $C$. anti$q u a$ and $K$. mikimotoi), and the bottom sediments obtained at Okimatsuura Fishing Port in Saiki City, Oita Prefecture, at concentrations of $1 \mathrm{~g} / \mathrm{L}$ and $0.1 \mathrm{~g} / \mathrm{L}$. Bottles were suspended at three depths $(0,5$, and $9 \mathrm{~m})$ at the coastal point of the Fisheries Research Division of Oita Prefecture (Imai et al. 2017c). Diatoms originating from resting stage cells in sediments proliferated and suppressed $C$ antiqua and $K$. mikimotoi, as evidenced by the diatoms becoming predominant in the phytoplankton community in seawater after the addition of sediments to the bottles. This result explains the phenomenon of the changes in phytoplankton assemblages (predominance of diatoms) observed in the water column following the bottom sediment perturbation by submarine tillage in the field.
Large-scale bottom sediment perturbation by submarine tillage trials were conducted in $5 \mathrm{~km}^{2}$ areas in the northern areas off Sakai City and off Kishiwada City in the middle of Osaka Bay twice in late January and once on 10 February 2020. As mentioned above, outbreaks of the toxic dinoflagellate A. catenella (group I) have expanded in Osaka Bay since 1994, and the maximum density has commonly been above $10^{3}$ cells $/ \mathrm{mL}$ in recent years (Fig. 2). The bottom sediment perturbation aims to suppress the growth of $A$. catenella (group I) in Osaka Bay. As a result of the perturbation, diatoms mainly consisting of the genera Skeletonema, Chaetoceros, and Leptocylindrus were continuously observed at high densities $>10^{3}$ cells $/ \mathrm{mL}$. In contrast, $A$. catenella (group I) did not reach warning threshold levels of 5 cells/ $\mathrm{mL}$, as defined by the Osaka Prefecture, during the month of February. An alarming density (10 cells/mL) was, however, exceeded in early March, more than 20 days after the perturbation; and a highest value of 31 cells $/ \mathrm{mL}$ was recorded near the entrance of Sakai Dejima Port on March 23. Compared with the occurrences of higher densities of $A$. catenella (group I) on the order of $10^{3}$ and $10^{4}$ cells $/ \mathrm{mL}$ over the past several years, this value ( 31 cells $/ \mathrm{mL}$ ) can be considered as successfully low, with the maximum cell density being $1 / 100$ or less compared with previous years. These results indicate that diatoms were successfully increased after the bottom sediment perturbation, suppressing A. catenella (group I) populations and maintaining low toxin levels in bivalves in Osaka Bay in 2020, as no regulated threshold levels of Manila clams or oysters were exceeded. Moreover, this low 

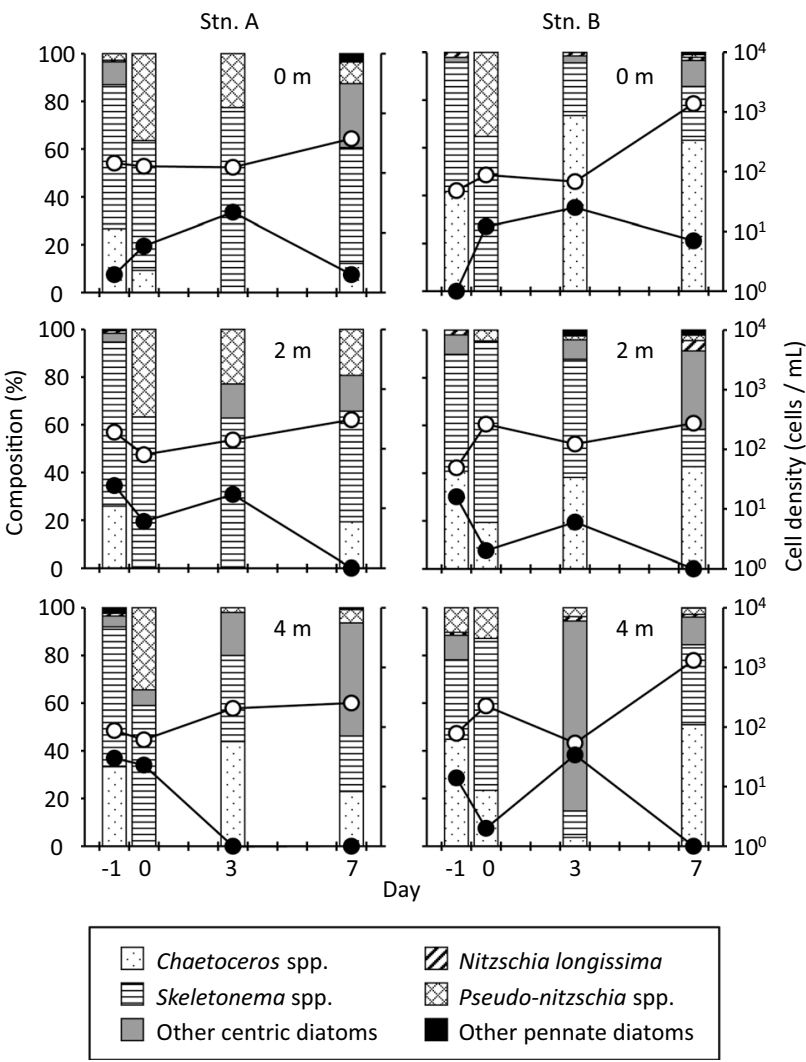

Fig. 8 Changes in cell densities of Chattonella ( ), diatoms ( $\bigcirc)$, and taxa composition histograms of diatoms at three depths $(0,2$, and $4 \mathrm{~m}$ ) at Stn. A (point outside bottom sediment tillage area) and B (point inside bottom sediment tillage area) in the coastal sea of Tomono-Ura of the Seto Inland Sea, from 7 July (day -1) to 15 July (day 7) 2016. Figure from Imai et al. (2017a)

Table 6 Conditions of experimental bottles (Fig. 9) with combinations of inoculation of red tide raphidophyte Chattonella antiqua and addition of nutrient source of SWM-3 medium. Data derived from Imai et al. (2017a)

\begin{tabular}{lll}
\hline Bottle & Chattonella antiqua & Nutrient addition \\
\hline a & No addition & No addition \\
$\mathrm{b}$ & No addition & SWM-3, 1/100 strength \\
$\mathrm{c}$ & 200 cells $/ \mathrm{mL}$ & No addition \\
$\mathrm{d}$ & 200 cells $/ \mathrm{mL}$ & SWM-3, 1/100 strength \\
\hline
\end{tabular}

level of bivalve toxicity is thought to increase the survival rate of higher trophic levels, such as octopuses, that prey on bivalves. The toxins of A. catenella (group I) were reported to be transferred and accumulated in zooplankton, leading to the death of animals at higher trophic levels (White 1981; White et al. 1989; Teegarden and Cembella 1996; Turner and Tester 1997). If nontoxic diatoms are predominant, the food webs in the corresponding waters will remain intact.

Details of the above results will be published in the near future (Yamamoto et al., in preparation). It is necessary to


Fig. 9 Changes in cell densities of Chattonella $(-)$, and diatoms $(\bigcirc)$, and taxa composition histograms of diatoms in the incubation bottle experiment. Sediment-suspended samples were collected at a depth of $2 \mathrm{~m}$ at Stn. B immediately following the bottom sediment tillage, and prepared bottles were incubated under the following conditions: temperature $25^{\circ} \mathrm{C}$, light intensity $50 \mu \mathrm{mol}$ photons $\cdot \mathrm{m}^{-2} \mathrm{~s}^{-1}$, and photocycle $14 \mathrm{~h}$ light: $10 \mathrm{~h}$ dark. See Table 6 for further explanation of bottles (a)-(d). Figure from Imai et al. (2017a)

continue the bottom sediment perturbation, together with devising the timing and scale of its implementation, to confirm the reproducibility of the results (diatom predominance with suppressed A. catenella (group I)), and to refine the technologies used. As a result, an effective, environmentally friendly method can be established to prevent outbreaks of toxic blooms, helping to ensure the safety of marine life and resources into the future.

\section{Theories and criteria for HAB controlling strategies}

In the field of agriculture, pest control is crucial for maintaining and improving production, and a great deal of research effort has been devoted to it. When farmed marine organisms are regarded as crops, the pests are equivalent to harmful algae. There are many similarities between HAB control in fisheries and pest control in agriculture, and applying the lessons from increasing crop productivity to marine resources can provide a number of useful perspectives.

In the past, Japanese agriculture adopted a defenseoriented strategy with a focus on plant protection from pests. A variety of organisms inhabited paddy and upland fields, passively preserving the biodiversity; however, novel 
synthetic pesticides developed after World War II changed the approach to pest control from "defensive" to "offensive." With the exception of agricultural crops, pest control was carried out based on a "disinfection policy," which does not permit the existence of pests and useful organisms, even beneficial insects and animals. As a result, serious issues have arisen, such as the appearance of drug-resistant organisms, dangers of residual pesticides in crops and the environment, and induction of abnormal pest occurrences. These problems have caused major destruction of the natural biota and ecosystem (Kiritani 1979; Naba 2001).

Assessing the direct methods of eliminating HABs, both physical and chemical methods can be regarded as measures exactly based on a "disinfection policy." There is no careful consideration of organisms other than the directly farmed marine life, and all marine organisms (the main target being harmful algae) are indiscriminately exterminated. In agriculture, paddy and upland fields are primarily two-dimensional fields; thus, pesticides accumulate after application and diffuse slowly to the external environment. On the other hand, the sea is a three-dimensional system with depth, being a fluid diffusion system with continuous water flow. Therefore, it can be concluded that control strategies based on spraying substances are implausible in the sea in terms of scale, economy, and environmental security.

Such pest control based on the "disinfection policy" was reconsidered in agriculture. Efforts have been made to combine various measures to minimize the use of pesticides in an approach named "integrated pest management" (IPM) (Kiritani 1997; Naba 2001). The official definition of IPM is "the pest population management systems for reducing pest densities below economic injury level (EIL) and maintaining pest densities lower level by using all appropriate control measures in a reasonable manner." The concept of EIL is drawing a line under the conventional "disinfection policy." Pests damage crops only when they reach a certain density, and even when surpassing this level, if the damage is less than the cost of pest control, it will be meaningless. The strict criteria for EIL will be the pest density at which the benefits of control are maximized. From this point of view, EIL varies depending on the crop, pest type, and control method. It should be acknowledged, however, that pests are not always controlled because of their occurrence but when economic damage is predicted. Therefore, pest control is both a technological and economic issue.

Following the framework established by the Convention on Biological Diversity (CBD), biodiversity should be maintained not only in natural environments but also in agricultural fields. It is necessary to maintain and/or improve the densities of endangered and rare species above the extinction threshold. However, in addition to the original pests, other insect species become pests at certain densities. Therefore, it is necessary to manage their densities as well so as not to exceed the EIL. This form of management is referred to as integrated biodiversity management (IBM). Since coexistence with various organisms is pursued without excluding other potential pest species, primary control policies are moving from IPM to IBM (Kiritani 2000).

The following are the comprehensive considerations on the relationships between countermeasures and the stage of red tide occurrences. Figure 10 shows a conceptual diagram for preventing and/or controlling the occurrences of red tides. The "damage causing level" corresponds to the aforementioned EIL. Preventive countermeasures must be implemented before the density of causative red tide organisms reaches the critical level, a point defined as the "control threshold" (CT), derived from the concept used in agricultural pest control. The CT can be set between the "background" and "damage-causing" levels. To best prevent and/ or control the occurrence of red tides, the dynamics of the targeted red tide organisms must be properly monitored, enabling prediction of the outbreaks themselves.

In the case of bottom sediment perturbation, if these actions are performed at the point of the CT of HAB species according to monitoring information, nutrient salts are expected to be consumed by the subsequent growth of diatoms, and the occurrence of red tides by harmful flagellates is likely to be prevented. With regards to red tide species that are susceptible to viruses, spraying of marine bottom sediments containing effective viruses has been reported to control harmful species populations, such as the bivalvekilling dinoflagellate $H$. circularisquama, through infection (Nakayama et al. 2020). In the early stages of dinoflagellate K. mikimotoi-induced red tides, a thin layer with high cell density is usually formed at the mid-depths of specific water areas (Uchida et al. 1998; Yamaguchi 1994; Miyamura 2016; Aoki et al. 2017). The initial destructive methods applied to this thin layer, such as clay spraying (Murata 2017), the movement of thin-layer populations to the surface (i.e., unsuitable depths for their growth and survival; Miyamura 2017), and the application of bottom sediment perturbation using dragnets (Imai et al. 2017a) with air bubbling when possible, are effective for suppressing K. mikimotoi populations. As for red tides exceeding the CT level and reaching the EIL when preventive or immediate control measures are unsuccessful, clay spraying is commonly applied as a last resort (particularly in aquaculture fisheries) to reduce the damage inflicted (Kagoshima Prefecture 1982, 2018; Kim 2006; Imai 2017b).

It is fundamentally important to prevent the occurrences of HABs over long timescales by the creation of water environments that naturally suppress the growth of HAB-causative organisms. The restoration and creation of seagrass and seaweed beds have been proposed as environmentally friendly strategies to prevent the occurrence of HABs (Imai et al. 2006a, 2017b; Imai 2015). Furthermore, the effects of 


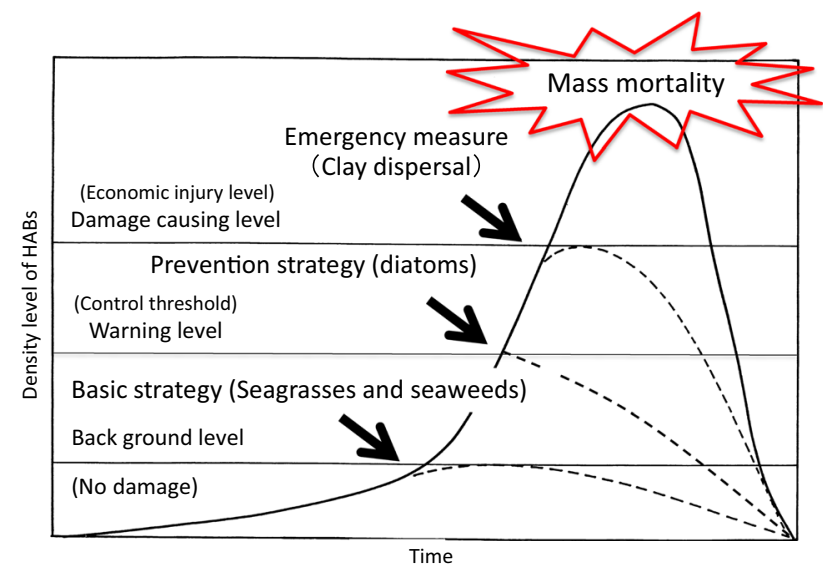

Fig. 10 Conceptual diagram for prevention and/or control of harmful algal blooms at each level of bloom development. Bold line shows the change in harmful algae with no strategy implemented, arrow shows the timing for the implementation of countermeasure technology, and dotted line shows the change in harmful algae concentrations after treatment. Data partly modified from Imai (2017b)

combined aquaculture of fish and seaweeds may be promising (Imai et al. 2002, 2012, 2020; Imai 2019; Inaba et al. 2020). These effects take advantage of the natural function of seaweeds and seagrasses, providing inhabitable substrates to algicidal and growth-inhibiting bacteria, which are then supplied to the surrounding waters. It is expected that the coastal marine ecosystem itself will self-maintain in a healthy state, with relatively higher densities of bacteria limiting algal growth, and in which phytoplankton communities containing $\mathrm{HAB}$ species do not proliferate into overscale and destructive blooms (Imai and Yamaguchi 2012; Imai 2015; Imai et al. 2017b).

As the ocean is home to a vast array of species and organisms, the minimum criterion that must be met for successful countermeasures to red tides is "When the implemented red tide control measures are successful or fail, they should not have significant adverse effects on the marine lives in the ecosystem" (Imai 2017a). Ultimately, simple technologies supported by profound ecological research could meet such criteria, thus preventing and controlling harmful algal blooms in feasible and environmentally friendly ways.

\section{Harmful cyanobacterial blooms and control strategies}

Cyanobacterial blooms have frequently occurred in lakes and reservoirs across the globe (except in polar regions), primarily due to eutrophication and climate change (O'Neil et al. 2012; Paerl and Otten 2013; Harke et al. 2016). Toxic and nuisance cyanobacterial blooms pose serious problems to water resource uses, such as drinking and agriculture.
There is a long history of deaths due to toxic cyanobacterial blooms in grazing livestock and wild animals (Stewart et al. 2008). For example, the recent deaths of 300 African elephants in Botswana in 2020 attracted international attention, and the cause is suspected to be toxic cyanobacterial blooms in drinking water ponds (https://www.bbc.com/ news/world-africa-54234396). Additionally, water toxified by the cyanobacterium Microcystis aeruginosa posed a great danger to US residents reliant upon water from Lake Erie, forcing drinking water to be imported by tanker trucks from distant areas (Steffen et al. 2017). In Japan, harmful and toxic cyanobacterial blooms have also posed critical environmental problems, such as interrupting the supply of drinking water, and spoiling landscapes that are important for tourism (Takamura 1988; Shimizu et al. 2016; Imai et al. 2019).

Regarding the control of these harmful cyanobacterial blooms, nutrient input reduction and breaking down stratification are both effective methods in small-scale reservoirs (Paerl and Otten 2013). Copper sulfate has been sprayed to exterminate cyanobacterial blooms in drinking water reservoirs, and activated charcoal has been used to deodorize water affected by odor-producing cyanobacteria. However, these chemical treatments have a high cost (Shimizu et al. 2016). Therefore, prevention and control of nuisance cyanobacterial blooms have become an urgent and critical issue.

Environmentally friendly biological control measures for cyanobacterial blooms have been extensively investigated (Sigee et al. 1999; Gumbo et al. 2008; Ndlela et al. 2018; Pal et al. 2018; Imai et al. 2019). In limnetic microbial ecology, investigations on useful microbes, such as algicidal bacteria and lytic viruses, have been actively pursued (Yamamoto 1988). Many studies have been conducted on the aquatic distribution of these microorganisms and the algicidal activities of isolates (Mitsutani et al. 1987; Manage et al. 2001; Kim et al. 2008; Shimizu et al. 2017). The biological suppression of harmful cyanobacterial blooms using these microorganisms has also been pursued (Sigee et al. 1999; Gumbo et al. 2008). However, the technology to appropriately utilize these microorganisms for the prevention and control of blooms has not yet reached the levels required for practical use on scales beyond the laboratory (Ndlela et al. 2018).

In Lake Biwa of Shiga Prefecture, and Lake Oshima Onuma of Hokkaido, bacteria showing algicidal and growthinhibiting activities against the toxic cyanobacterium Microcystis aeruginosa have recently been discovered in aquatic plants such as the emerging plant Phragmites australis, the floating-leaved plant Trapa japonica, and the submerged plants Myriophyllum verticillatum and Utricularia vulgaris. A new discovery is that effective (algicidal and growthinhibiting) bacteria are found to inhabit the surface biofilm of water plants at high densities (Imai 2010a; Kojima et al. 2016; Daido et al. 2018; Miyashita et al. 2019). Maximum 
densities on the order of $10^{4} \mathrm{CFU} / \mathrm{mL}$ in water, and $10^{6}$ to $10^{8} \mathrm{CFU} / \mathrm{g}$ (wet weight) were detected for these effective bacteria in aquatic plants (Table 7). For example, from the surface biofilm of reed stems collected in Lake Oshima Onuma, the detected densities of these bacteria effective against $M$. aeruginosa were $5.2 \times 10^{5}-4.8 \times 10^{6} \mathrm{CFU} / \mathrm{g}$ (wet weight; Fig. 11), and the densities of these bacteria in waters of reed belt were $4.3 \times 10^{1}-2.4 \times 10^{3} \mathrm{CFU} / \mathrm{mL}$ (Kojima et al. 2016). A co-culture experiment was also conducted by adding lake water collected from the reed zone near the campsite on the northeast coast of Lake Oshima Onuma to a sample of $M$. aeruginosa bloom collected at Onuma Port (Imai et al. 2014). As a result, a decrease in $98 \%$ of $M$. aeruginosa was recorded at $1 / 10$ addition, $94 \%$ at $1 / 100$ addition, and $78 \%$ at $1 / 1000$ addition. Comparatively, no decrease in $M$. aeruginosa cells was observed in the control sample bottle without addition of lake water collected in the reed zone. Thus, the presence of certain aquatic plants is thought to supply bacteria that have the ability to suppress the growth of nuisance cyanobacteria to the surrounding water, probably decreasing the frequency and severity of cyanobacterial blooms in lakes and ponds.

An antagonistic relationship between aquatic plants and phytoplankton has long been documented in lake ecosystems (Hogetsu et al. 1960; Nemoto and Fukuhara 2012). One such study reported long-term observations in a Swedish lake, documenting distinct antagonistic relationships between aquatic plants and phytoplankton (Blindow et al. 1998). During the period of limited nutrient loadings, the lake water was transparent, phytoplankton biomass was small, submerged plants proliferated widely, and fish-eating fishes were abundant. Alternatively, as nutrient loading increased and eutrophication progressed, phytoplankton biomass increased sharply, and the lake water became turbid due to the predominance of cyanobacteria, leading to the disappearance of submerged aquatic plants and the dominance of plankton-eating fishes. In this way, there are generally two stable states in lake ecosystems: "transparent" and "turbid" (Scheffer et al. 2001; Scheffer and Jeppesen 2007; Schallenberg and Sorrel 2009). However, in a turbid lake, a "transparent state" was partially observed in some areas where aquatic plants were growing well (Scheffer et al. 1994).

As a mechanism of the antagonistic relationship between aquatic plants and phytoplankton, allelopathy by aquatic plants has been proposed previously (Hogetsu et al. 1960; Nakai et al. 2000). However, as mentioned above, aquatic plants harbor enormous densities of cyanobactericidal and growth-inhibiting bacteria (Table 7). A significant negative correlation was observed between the distribution densities of M. aeruginosa, and cyanobactericidal bacteria and growth-inhibiting bacteria in the lakes of Onuma QuasiNational Park, Hokkaido (Miyashita et al. 2019). From

Table 7 Summary of published studies on algicidal or growth-inhibiting bacteria targeting nuisance bloom species in freshwater systems associated with aquatic plants

\begin{tabular}{|c|c|c|c|c|c|c|}
\hline Sampling site & Year & Source & Target HAB species & $\begin{array}{l}\text { Maximum density } \\
\text { of } A B \text { and GIB }\end{array}$ & Remark & Ref. \\
\hline \multirow[t]{2}{*}{ Lake Biwa } & \multirow[t]{2}{*}{2007} & Water & $\begin{array}{l}\text { Microcystis aerugi- } \\
\quad \text { nosa }\end{array}$ & $2.0 \times 10^{4} \mathrm{CFU} / \mathrm{mL}$ & Reed belt & \multirow[t]{2}{*}{ Imai (2010a) } \\
\hline & & Phragmites australis & M. aeruginosa & $9.8 \times 10^{6} \mathrm{CFU} / \mathrm{g}$ & Emerging plant & \\
\hline $\begin{array}{l}\text { Onuma Quasi- } \\
\text { National Park, } \\
\text { Hokkaido }\end{array}$ & 2013 & $\begin{array}{l}\text { Water } \\
\text { Phragmites australis }\end{array}$ & $\begin{array}{l}\text { M. aeruginosa } \\
\text { M. aeruginosa }\end{array}$ & $\begin{array}{l}2.4 \times 10^{3} \mathrm{CFU} / \mathrm{mL} \\
4.8 \times 10^{6} \mathrm{CFU} / \mathrm{g}\end{array}$ & $\begin{array}{l}\text { Water plant zone } \\
\text { Emerging plant }\end{array}$ & Kojima et al. (2016) \\
\hline \multirow{3}{*}{$\begin{array}{l}\text { Goryokaku Park } \\
\text { Moat, Hakodate }\end{array}$} & \multirow[t]{3}{*}{2015} & Water & M. aeruginosa & & Water plant zone & \multirow[t]{3}{*}{ Daido et al. (2018) } \\
\hline & & $\begin{array}{l}>3 \mu \mathrm{m} \text { fraction } \\
<3 \mu \mathrm{m} \text { fraction }\end{array}$ & & $\begin{array}{l}7.8 \times 10^{3} \mathrm{CFU} / \mathrm{mL} \\
1.3 \times 10^{4} \mathrm{CFU} / \mathrm{mL}\end{array}$ & & \\
\hline & & Trapa japonica & M. aeruginosa & $2.7 \times 10^{7} \mathrm{CFU} / \mathrm{g}$ & Floating-leaved plant & \\
\hline \multirow[t]{6}{*}{$\begin{array}{l}\text { Onuma Quasi- } \\
\text { National Park, } \\
\text { Hokkaido }\end{array}$} & \multirow[t]{6}{*}{2012} & $\begin{array}{l}\text { Water } \\
>3 \mu \mathrm{m} \text { fraction } \\
<3 \mu \mathrm{m} \text { fraction }\end{array}$ & M. aeruginosa & $\begin{array}{l}4.4 \times 10^{4} \mathrm{CFU} / \mathrm{mL} \\
4.5 \times 10^{3} \mathrm{CFU} / \mathrm{mL}\end{array}$ & Water plant zone & \multirow[t]{6}{*}{ Miyashita et al. (2019) } \\
\hline & & Trapa japonica & M. aeruginosa & & Floating-leaved plant & \\
\hline & & Leaf & & $1.2 \times 10^{7} \mathrm{CFU} / \mathrm{g}$ & & \\
\hline & & Water root & & $1.4 \times 10^{8} \mathrm{CFU} / \mathrm{g}$ & & \\
\hline & & $\begin{array}{l}\text { Myriophyllum verti- } \\
\text { cillatum }\end{array}$ & & $1.1 \times 10^{7} \mathrm{CFU} / \mathrm{g}$ & Submerged plant & \\
\hline & & Utricularia vulgaris & & $9.2 \times 10^{6} \mathrm{CFU} / \mathrm{g}$ & Submerged plant & \\
\hline
\end{tabular}

Bacterial densities were determined with the method of bacterial isolation and co-culture experiment

$H A B$ harmful algal bloom, $A B$ algicidal bacteria, $G I B$ growth-inhibiting bacteria, $C F U$ colony forming unit 


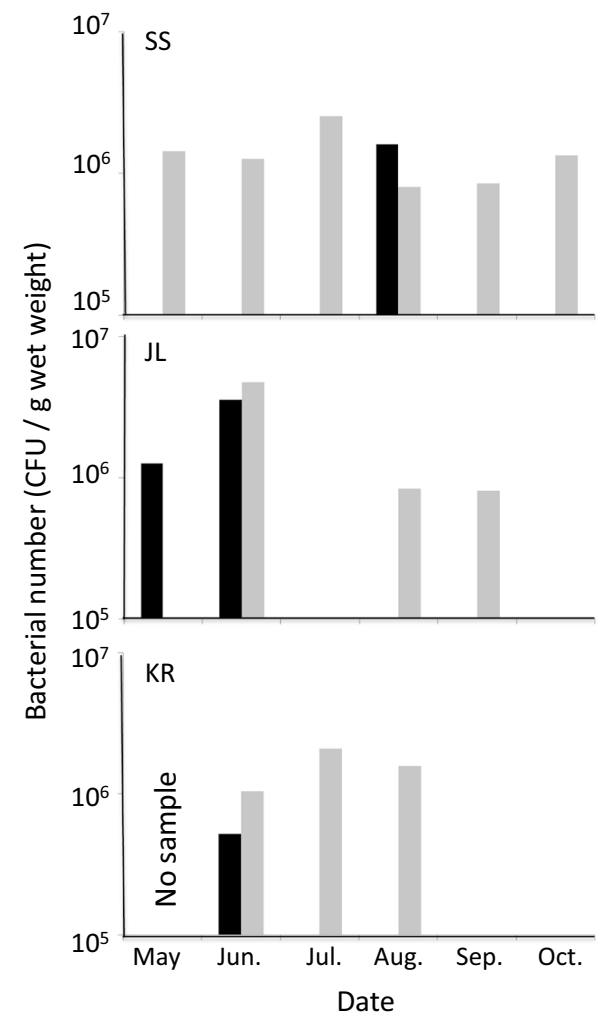

Fig. 11 Number of algicidal bacteria (black column) and growthinhibiting bacteria (gray column) against toxic cyanobacterium Microcystis aeruginosa detected from biofilm of reed stem samples collected at Sansui (SS), Junsainuma Lake (JL), and Karima River (KR) in Onuma Quasi-National Park, Hokkaido. Figure from Kojima et al. (2016)

these results, the activities of abundant cyanobactericidal and growth-inhibiting bacteria inhabiting the biofilm on the surface of aquatic plants can form the basis of a newly proposed mechanism driving the antagonistic relationship between aquatic plants and phytoplankton. Taking these bacterial activities into consideration, the occurrence of cyanobacterial blooms would be suppressed by systematically creating water plant zones and appropriately managing them in lakes with frequent cyanobacterial blooms (Imai et al. 2019; Miyashita et al. 2019). It is worth accumulating further case studies on the application of water plants to examine the prevention of cyanobacterial blooms in the future.

\section{Overview and future challenges}

The Seto Inland Sea is a representative, semiclosed water area in Japan. Severe eutrophication was once persistent during an era of rapid economic growth, and the shallow coastal ecosystems, including seaweed and seagrass beds, tidal flats, and shallow sea areas, were lost on a large scale due to intensive reclamation. Considering the massive existence of effective bacteria (algicidal and growth-inhibiting bacteria) inhabiting seagrass and seaweed beds, the disappearance of these habitats means the loss of these effective bacteria on a large scale, which in turn influences the frequency and strength of HABs.

The restoration and creation of coastal seaweed and seagrass beds to prevent the occurrence of HABs should be put forward as part of the Sato-Umi Initiative (Fig. 12). The term "Sato-Umi" is defined as "a coastal area where bioproductivity and biodiversity have increased due to human intervention" (Yanagi 2008). In this sense, red tides can be regarded as the extreme state of biodiversity impairment, since a single phytoplankton species dominates the entire aquatic region. It is presumed that effective bacteria derived from seaweeds and seagrasses will be continuously supplied to the surrounding water, spreading to the adjacent water bodies, and preventing the occurrence of harmful algal blooms (Imai and Yamaguchi 2012; Imai 2015). This situation appears to correspond to the "clear state" of a lake system, with little phytoplankton biomass when aquatic plants are abundant. It should be emphasized that targeted planning of seawater passing through seaweed and/or seagrass beds and affecting HAB areas is the key to maximizing their effects.

Shallow coastal ecosystems such as seaweed beds, seagrass beds, and tidal flats support rich biodiversity, biomass, and are extremely important as a system for natural water purification and fostering juvenile marine life (Duffy 2006; Orth et al. 2006; Mukai 2011; Furukawa 2016; Nakaoka et al. 2017; Cullen-Unsworth and Unsworth 2018). Nutrients and organic matter loaded into the shallow waters of coastal areas are quickly taken up by various marine organisms, occupying multiple food webs, such as epiphytic microalgae (mainly pennate diatoms), bacteria, protozoa, sessile and phytal animals, etc. Furthermore, these nutrients and organic matter are retained by animals and plants with relatively long lifetimes. Therefore, it can be understood that the growth of phytoplankton is a flow of nutrients on a much shorter timescale, and prevented mainly through benthic/ epiphytic diatoms in tidal flats, seaweed, and seagrass beds. From the viewpoint of material cycling, these habitats have the ability to prevent the occurrence of exceptional phytoplankton blooms (Imai et al. 2017b).

In freshwater ecosystems, many cyanobactericidal bacteria have also been found on the surfaces of reed stems, submerged and floating-leaved plants (Table 7). Although there are abundant differences between the sea and inland waters, there appears to be a shared phenomenon between seaweeds and seagrasses in the sea, and aquatic plants in lakes and ponds providing excellent habitats for effective bacteria that are expected to control phytoplankton dynamics. Therefore, the Sato-Umi concept for coastal waters can be adapted to freshwater systems as well (Fig. 13). Moreover, in terms of 


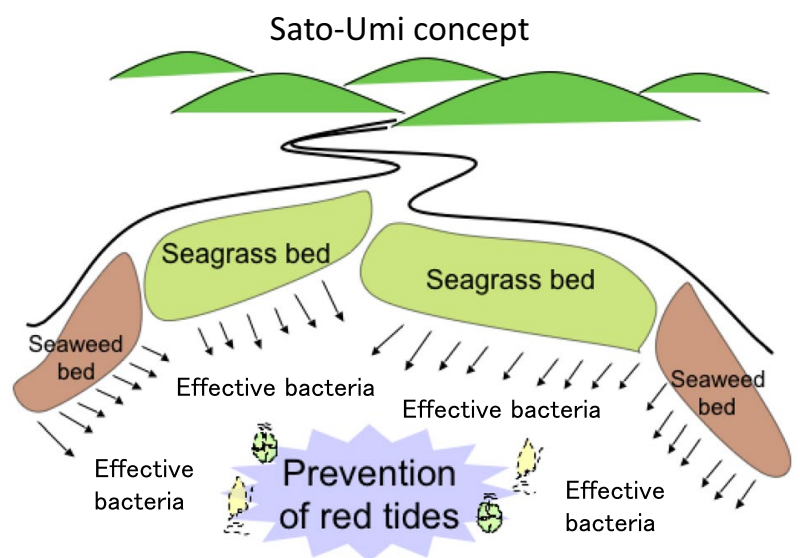

Fig. 12 Schematic representation of preventive strategies for red tide occurrence by restoration and/or development of seaweed and seagrass beds in coastal areas under the concept of "Sato-Umi." Effective bacteria (algicidal bacteria + growth-inhibiting bacteria) would be added to seawater, preventing red tide occurrences by suppressing phytoplankton populations to moderate levels. Figure from Imai et al. (2009)

maintaining and acquiring clean water resources, such as drinking water, the aquatic plant zone must be the focus of greater research efforts, as it is expected to mitigate the toxification and odorization of lake water. With these situations in mind, water plant management involving some budgetary measures in lake systems is thought to be reasonable. It is essential to properly interact with lakes and keep them healthy for future generations.

It has been pointed out that the occurrence of HABs is greatly affected by climate change, especially increasing global temperatures (Trainer et al. 2020; Wells et al. 2020). Water temperature is on the rise in the Seto Inland Sea, and representative summer red tides of Chattonella, which historically occurred in August until the mid-1990s, have been starting approximately one month earlier in July over the past $\sim 25$ years (Nishikawa et al. 2014). Since the germination time of cysts would accelerate due to warming, it would follow that the formation of Chattonella red tides would also occur earlier. In the summer of 2014, the raphidophyte Chattonella marina, and the dinoflagellate $M$. polykrikoides were detected for the first time along the coast of Yoichi, Hokkaido, northern Japan (Shimada et al. 2016a). In addition, red tides by the harmful dinoflagellate $K$. mikimoto $i$ were detected, resulting in mortality of salmon and squid in Hakodate Bay, Hokkaido, for the first time in 2015 (Shimada et al. 2016b; Kakumu et al. 2018). Moreover, the bivalvekilling dinoflagellate $H$. circularisquama has expanded its red tide range northward up to Lake Kamo on Sado Island in the Sea of Japan (Kondo et al. 2012). These trends imply that other red tides that presently occur in southwest Japan will expand to the northeast on the side of the Sea of Japan. Toxifications of useful bivalve mollusks with toxic dinoflagellates have been a great threat to the coastal waters of Tohoku and Hokkaido to date, but the potential of further bivalve mortality driven by harmful red tides may be added in the near future. The problem of harmful algal blooms shows no signs of decreasing, and since the social needs for scientific research on HABs are not decreasing either, further investigations and practical applications of prospective technologies are necessary for controlling HABs.
Fig. 13 The concept of "SatoUmi" initiatives in lake systems, such as Lake Onuma, where the management of aquatic plants is proposed to be a key process. Figure from Imai et al. (2019)

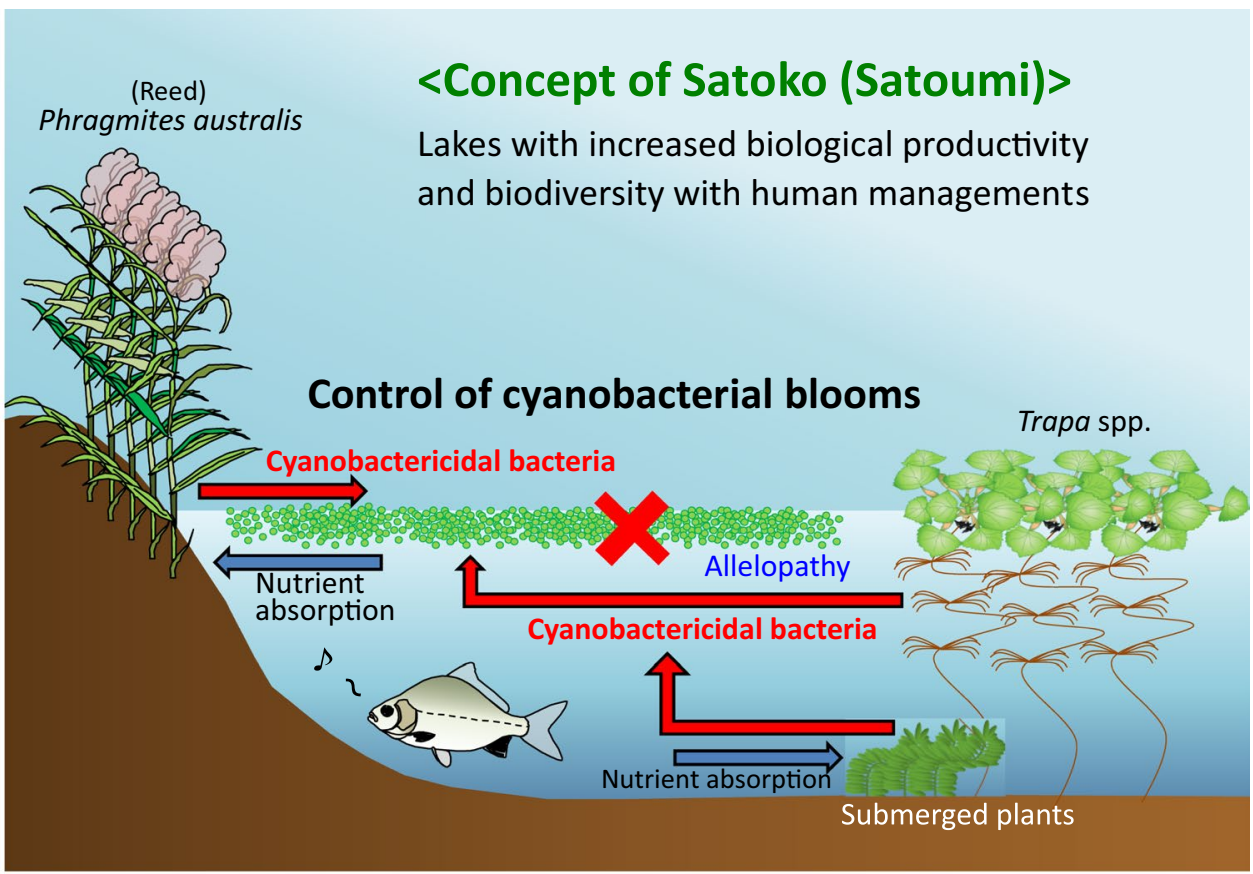


Acknowledgements The dedicated contributions of the students of Kyoto and Hokkaido University involved in the investigations on HABs are deeply appreciated. Studies in this article were supported in part by grants from the Fisheries Agency of Japan. The publication of this review was also supported by the Japan Society for the Promotion of Science KAKENHI JP19HP2002. We would like to thank Editage (www.editage.com) for English language editing.

Open Access This article is licensed under a Creative Commons Attribution 4.0 International License, which permits use, sharing, adaptation, distribution and reproduction in any medium or format, as long as you give appropriate credit to the original author(s) and the source, provide a link to the Creative Commons licence, and indicate if changes were made. The images or other third party material in this article are included in the article's Creative Commons licence, unless indicated otherwise in a credit line to the material. If material is not included in the article's Creative Commons licence and your intended use is not permitted by statutory regulation or exceeds the permitted use, you will need to obtain permission directly from the copyright holder. To view a copy of this licence, visit http://creativecommons.org/licenses/by/4.0/.

\section{References}

Adachi M (2016) Ecology and physiology of benthic toxic dinoflagellates. In: Imai I, Yamaguchi M, Matsuoka K (eds) Advances in harmful algal bloom research. Koseisha-Koseikaku, Tokyo, pp 324-333 (in Japanese)

Anderson DM (2017) Harmful algal blooms. In: Anderson DM, Boerlage SFE, Dixon MB (eds) Harmful algal blooms (HABs) and desalination: a guide to impacts, monitoring and management. Manuals and guide 78. IOC-UNESCO, Paris, pp 17-52

Anderson DM, Glibert PM, Burkholder JM (2002) Harmful algal blooms and eutrophication: nutrient sources, composition, and consequences. Estuaries 25:704-726

Aoki K, Kameda T, Yamatogi T, Ishida N, Hirae S, Kawaguchi M, Syutou T (2017) Spatio-temporal variations in bloom of the redtide dinoflagellate Karenia mikimotoi in Imari Bay, Japan, in 2014: factors controlling horizontal and vertical distribution. Mar Poll Bull 124:130-138

Baker SM, Levinton JS, Kurdziel JP, Shumway SE (1998) Selective feeding and biodeposition by zebra mussel and their relation to changes in phytoplankton composition and seston load. J Shellfish Res 17:1207-1213

Blindow I, Hargeby A, Anderson G (1998) Alternative stable states in shallow lakes-what causes a shift? In: Jeppesen E, Sondergaard $\mathrm{M}$, Christoffersen K (eds) The structuring role of submerged macrophytes in lakes. Springer, Berlin, pp 353-368

Constanza R, d'Arge R, de Groot R, Farber S, Grasso M, Hannon B, Limburg K, Naeem S, O’Neill RV, Paruelo J, Raskin RG, Sutton P, van den Belt M (1997) The value of the world's ecosystem services and natural capital. Nature 387:253-260

Cullen-Unsworth LC, Unsworth R (2018) A call for seagrass protection. Science 361:446-448

Daido H, Miyashita Y, Kobayashi J, Oda S, Tanaka K, Yamaguchi A, Imai I (2018) Seasonal fluctuation of algicidal and growthinhibiting bacteria against the toxic bloom forming cyanobacterium Microcystis aeruginosa, detected from the water plant Trapa jeholensis $(=T$. japonica) and surrounding water. Jpn J Phycol (Sorui) 66:111-117 (in Japanese with English abstract)

Duffy JE (2006) Biodiversity and the functioning of seagrass ecosystems. Mar Ecol Prog Ser 311:233-250
Fisheries Agency (2020a) Red tides in the Seto Inland Sea in 2019. Kobe, p 62 (in Japanese)

Fisheries Agency (2020b) Red tides in the Kyushu coasts in 2019. Fukuoka, p 121 (in Japanese)

Fukuyo Y (2000) Perspectives of research direction on toxic algal blooms. In: Ishida Y, Honjo T, Fukuyo Y, Imai I (eds) Mechanisms, prediction, and mitigation of harmful algal blooms in Japan. Japan Fisheries Resource Conservation Association, Tokyo, pp 18-28

Fuqua WC, Sc W, Greenberg EP (1994) Quorum sensing in bacteria: the LuxR-LuxI family of cell density-responsive transcriptional regulators. J Bacteriol 176:269-275

Furukawa K (2016) Status of Japanese coasts and role of wetland restoration. J Japan Soc Water Environ 39A(4):116-119 (in Japanese)

Gumbo RJ, Ross G, Cloete ET (2008) Biological control of Microcystis dominated harmful algal blooms. Afr J Biotechnol 7:4765-4773

Gustafson DE Jr, Stoecker DK, Johnson MD, van Heukelem WF, Sneider K (2000) Cryptophyte algae are robbed of their organelles by the marine ciliate Mesodinium rubrum. Nature 405:1049-1052

Hallegraeff GM (1993) A review of harmful algal blooms and their apparent global increase. Phycologia 32:79-99

Harke MJ, Steffen MM, Gobler CJ, Otten TG, Wilhelm SW, Wood SA, Paerl HW (2016) A review of the global ecology, genomics, and biogeography of the toxic cyanobacterium, Microcystis spp. Harmful Algae 54:4-20

Heisler J, Glibert PM, Burkholder JM, Anderson DM, Cochlan W, Dennison WC, Dortch Q, Gobler CJ, Heil CA, Humphries E, Lewitus A, Magnien R, Marshall HG, Sellner K, Stockwell DA, Stoecker DK, Suddleson M (2008) Eutrophication and harmful algal blooms: a scientific consensus. Harmful Algae 8:3-13

Hogetsu K, Okanishi Y, Sugawara H (1960) Studies on the antagonistic relationship between phytoplankton and rooted aquatic plants. Jpn J Limnol 21:124-130 (in Japanese with English summary)

Iioka M (2017) The new guideline for risk management for measures for shellfish toxins. In: Suzuki T, Kamiyama T, Oshima Y (eds) The new guideline for risk management measures for shellfish toxins and investigation on its implementation. Koseisha-Koseikaku, Tokyo, pp 27-35 (in Japanese)

Imai I (1997) Algicidal ranges in killer bacteria of direct attack type for marine phytoplankton. Bull Plankton Soc Japan 44:3-9 (in Japanese with English abstract)

Imai I (2010a) Ecology and physiology of anti-Microcystis bacteria in reed (Phragmites australis) communities. IFO Res Commun 24:201-212 (in Japanese with English abstract)

Imai I (2010b) Sediment perturbation as a control strategy for noxious red tide occurrences. Aquabiology 32:378-379 (in Japanese with English abstract)

Imai I (2010c) Biology and ecology of harmful algal blooms (10): Grazers of Chattonella in coastal sea. Aquabiology 32:371-378 (in Japanese with English abstract)

Imai I (2011) Biology and ecology of harmful algal blooms (15): Killing mechanisms of red tide plankton by algicidal bacteria-1. Aquabiology 33:254-259 (in Japanese with English abstract)

Imai I (2012) Biology and ecology of Chattonella red tides. SeibutsuKenkyusha, Tokyo, p 184 (in Japanese)

Imai I (2013) Occurrence of Chattonella red tide and distribution of marine bacteria in Harima-Nada of the Seto Inland Sea in summer. Bull Fish Sci Hokkaido Univ 63:7-11 (in Japanese with English abstract)

Imai I (2015) Interactions between harmful algae and algicidal and growth-inhibiting bacteria associated with seaweeds and seagrasses. In: Ohtsuka S, Suzaki T, Horiguchi T, Suzuki N, Not F 
(eds) Marine protists: Diversity and dynamics. Springer Japan, Tokyo, pp 597-619

Imai I (2017a) Characteristics of red tide-causing plankton and promising and/or practical measures for harmful algal blooms. Aquacult Bus 54(3):3-7 (in Japanese)

Imai I (2017b) Red tide countermeasures improved to practical stagereduction of fishery damage begins with monitoring. Aquacult Bus 54(7):56-59 (in Japanese)

Imai I (2019) Environment-friendly prevention strategies for harmful algal blooms in coastal sea through poly-cultures of fishes and seaweeds. Kaiyo Mon 51:247-253 (in Japanese)

Imai I, Itakura S (2007) History of shellfish poisonings and fisheries damages in Japan. In: Imai I, Fukuyo Y, Hiroishi S (eds) Advanced researches on shellfish poisonings: current status and overview. Koseisha-Koseikaku, Tokyo, pp 9-18 (in Japanese)

Imai I, Yamaguchi M (2012) Life cycle, physiology, ecology and red tide occurrences of the fish-killing raphidophyte Chattonella. Harmful Algae 14:46-70

Imai I, Yoshinaga I (2002) Prevention and extermination of red tides. In: Imanaka T (ed) Great development of microorganisms. NTS, Tokyo, pp 881-888 (in Japanese)

Imai I, Itakura S, Itoh K (1990) Distribution of diatom resting cells in sediments of Harima-Nada and northern Hiroshima Bay, the Seto Inland Sea, Japan. Bull Coast Oceanogr 28:75-84 (in Japanese with English abstract)

Imai I, Ishida Y, Hata Y (1993) Killing of marine phytoplankton by a gliding bacterium Cytophaga sp., isolated from the coastal sea of Japan. Mar Biol 116:527-532

Imai I, Ishida Y, Sakaguchi K, Hata Y (1995) Algicidal marine bacteria isolated from northern Hiroshima Bay, Japan. Fish Sci 61:628-636

Imai I, Itakura S, Yamaguchi M, Honjo T (1996) Selective germination of Heterosigma akashiwo (Raphidophyceae) cysts in bottom sediments under low light conditions: a possible mechanism of red tide initiation. In: Yasumoto T, Oshima Y, Fukuyo Y (eds) Harmful and toxic algal blooms. IOC-UNESCO, Paris, pp 197-200

Imai I, Kim MC, Nagasaki K, Itakura S, Ishida Y (1998a) Relationships between dynamics of red tide-causing raphidophycean flagellates and algicidal micro-organisms in the coastal sea of Japan. Phycol Res 46:139-146

Imai I, Nakagiri S, Nagai K, Nagasaki K, Itakura S, Yamaguchi M (1998b) Fluctuations of algicidal microorganisms against the harmful dinoflagellate Heterocapsa circularisquama in Ago Bay, Mie Prefecture, Japan. Bull Nansei Natl Fish Res Inst 31:53-61 (in Japanese with English abstract)

Imai I, Sunahara T, Nishikawa T, Hori Y, Kondo R, Hiroishi S (2001) Fluctuations of the red tide flagellates Chattonella spp. (Raphidophyceae) and the algicidal bacterium Cytophaga sp. in the Seto Inland Sea. Mar Biol 138:1043-1049

Imai I, Fujimaru D, Nishigaki T (2002) Co-culture of fish with macroalgae and associated bacteria: a possible mitigation strategy for noxious red tide in enclosed coastal sea. Fish Sci 68(Supplement):493-496

Imai I, Yamaguchi M, Hori Y (2006a) Eutrophication and occurrences of harmful algal blooms in the Seto Inland Sea, Japan. Plankton Benthos Res 1:71-84

Imai I, Fujimaru D, Nishigaki G, Kurosaki M, Sugita H (2006b) Algicidal bacteria isolated from the surface of seaweeds from the coast of Osaka Bay in the Seto Inland Sea, Japan. Afr J Mar Sci 28:319-323

Imai I, Yamamoto T, Ishii KI, Yamamoto K (2009) Promising prevention strategies for harmful red tides by seagrass beds as enormous sources of algicidal bacteria. In: Proceedings of 5th World Fisheries Congress. TERRAPUB, Tokyo, 6c_0995_133

Imai I, Okamoto S, Nishigaki T, Yoshinaga I, Takeuchi T (2012) Distribution of algicidal bacteria against red tide phytoplankton in seawater and on the surface of the green alga Ulva pertusa in Shimo-Haya Bay, Wakayama Prefecture. Bull Fish Sci Hokkaido Univ 62:21-28 (in Japanese with English abstract)

Imai I, Ohgi K, Mizuhara S, Yamaguchi A, Kaeriyama M (2014) Control of Microcystis aeruginosa bloom by waters from reed community and water plant bed. In: Kim HG, Reguera B, Hallegraeff GM, Lee CK, Han MS, Choi JK (eds) Harmful Algae 2012, Proceedings of the 15th International Conference on Harmful Algae. International Society for the Study of Harmful Algae, pp 184-187

Imai I, Yamamoto T, Ishii KI, Inaba N, Yamamoto K (2016) Prevention of harmful algal blooms by algicidal bacteria associated with eelgrasses. J Water Waste 58:295-300 (in Japanese)

Imai I, Kakumu A, Ohara S, Yuki T, Koike K, Hagiwara E, Ogawa K, Yoneyama H (2017a) Feasibility studies on sediment perturbation as control strategies for Chattonella red tides. Bull Fish Sci Hokkaido Univ 67:57-66 (in Japanese with English abstract)

Imai I, Inaba N, Sakami T (2017b) Environmentally friendly strategies for the prevention of harmful algal blooms using algicidal bacteria associated with seagrass beds. In: Proenca LAO, Hallegraeff GM (eds) Marine and fresh-water harmful algae. Proceedings of the 17th international conference on harmful algae. ISSHA 2017, pp 160-165

Imai I, Imai Y, Morita K, Miyamura K, Noda M, Ishii KI (2017c) In situ bottle experiments demonstrating feasibility of diatom resting stage cells in sediments to prevent red tides of noxious flagellates. In: JSGFS 85th Anniversary-Commemorative International Symposium "Fisheries Science for Future Generations", No. 05007

Imai I, Miyashita Y, Kobayashi J, Daido Y (2019) Eutrophication and occurrences of nuisance cyanobacterial blooms in Lake Onuma, and possible environment-friendly control strategies of blooms using cyanobacteriacidal bacteria on water plants. Trans Jpn Geomorphol Union 40:77-91 (in Japanese with English abstract)

Imai I, Kawaguchi M, Inaba N, Yamamoto K (2020) Biological control of toxic and noxious algal blooms with environment-friendly strategies. Kaiyo Mon 52:217-226 (in Japanese)

Inaba N, Watanabe T, Sakami T, Nishi H, Tahara Y, Imai I (2014) Temporal and spatial distribution of algicidal and growth-inhibiting bacteria in the coastal sea of southwest Japan. J Plankton Res 36:388-397

Inaba N, Trainer VL, Onishi Y, Ishii KI, Wyllie-Echeverria S, Imai I (2017) Algicidal and growth-inhibiting bacteria associated with seagrass and macroalgae beds in Puget Sound, WA, USA. Harmful Algae 62:136-147

Inaba N, Trainer VL, Nagai S, Kojima S, Sakami T, Takagi S, Imai I (2019) Dynamics of seagrass bed microbial communities in artificial Chattonella blooms: a laboratory microcosm study. Harmful Algae 84:139-150

Inaba N, Kodama I, Nagai S, Shiraishi T, Matsuno K, Yamaguchi A, Imai I (2020) Distribution of harmful algal growth-limiting bacteria on artificially introduced Ulva and natural macroalgal beds. Appl Sci. https://doi.org/10.3390/app10165658

Ishida M, Sonda Y (2003) Blooming of Alexandrium tamarense and increasing of toxicity of short-necked-clam in Mikawa Bay. Bull Aichi Fish Res Inst 10:25-36 (in Japanese with English abstract)

Ishikawa A, Hattori M, Miyama H, Imai I (2007) Abundance and distribution of Alexandrium spp. resting cysts in the surface sediments of Ise Bay and Mikawa Bay, central part of Japan. Bull Jpn Soc Fish Oceanogr 71:183-189 (in Japanese with English abstract)

Ishikawa T, Kusaka K, Oshino A, Nishitani G, Kamiyama T (2015) Distribution patterns of Alexandrium vegetative cells and resting cysts, and paralytic shellfish poisoning in Kesennuma Bay, 
after the Great East Japan Earthquake. Nippon Suisan Gakkaishi 81:256-266 (in Japanese with English abstract)

Itakura S (2000) Physiological ecology of the resting stage cells of coastal planktonic diatoms. Bull Fish Environ Inland Sea 2:67130 (in Japanese with English abstract)

Itakura S, Imai I (2014) Economic impacts of harmful algal blooms on fisheries and aquaculture in western Japan - an overview of interannual variability and interspecies comparison. In: Trainer VL and Yoshida T (eds) Proceedings of the workshop on economic impacts of harmful algal blooms on fisheries and aquaculture. PICES, Sidney, Canada, pp 17-26

Itakura S, Nagasaki K, Yamaguchi M, Imai I (1996) Species succession between Skeletonema costatum and Heterosigma akashiwo in Hiroshima Bay, Japan, with special reference to the resting stage cells in the bottom sediments. In: Yasumoto T, Oshima Y, Fukuyo Y (eds) Harmful and toxic algal blooms. IOC-Unesco, Paris, pp 373-376

Itakura S, Imai I, Itoh K (1997) "Seed bank" of coastal planktonic diatoms in bottom sediments of Hiroshima Bay, Seto Inland Sea, Japan. Mar Biol 128:497-508

Itakura S, Nagasaki K, Yamaguchi M, Imai I (1999) Abundance and spatial distribution of viable resting stage cells of planktonic diatoms in bottom sediments of the Seto Inland Sea, Japan. In: Mayama S, Idei M, Koizumi S (eds) 14th Diatom Symposium 1996. Koeltz Scientific Books, Koenigstein, pp 213-226

Itakura S, Yamaguchi M, Yoshida M, Fukuyo Y (2002) The seasonal occurrence of Alexandrium tamarense (Dinophyceae) vegetative cells in Hiroshima Bay, Japan. Fish Sci 68:77-86

Jacobs-Palmer E, Gallego R, Ramón-Raca A, Kunselman E, Cribari K, Horwith M, Kelly RP (2020) A halo of reduced dinoflagellate abundance in and around eelgrass beds. PeerJ 8:e8869

Kagoshima Prefecture (1982) Manual for preventing red tide damages with clay spraying. Kagoshima, p 31 (in Japanese)

Kagoshima Prefecture (2018) Manual for preventing red tide damages by using of modified clay. Kagoshima, p 20 (in Japanese)

Kakumu A, Morita K, Shimada H, Yamaguchi A, Imai I (2018) First detection of the noxious red tide dinoflagellate Karenia mikimotoi and bloom dynamics in 2015 and 2016 in Hakodate Bay, Hokkaido, northern Japan. Bull Plankton Soc Japan 65:1-11 (in Japanese with English abstract)

Kamiyama T (2017) Shellfish toxification and characteristics of the causative phytoplankton in major bivalve production areas in Japan. In: Suzuki T, Kamiyama T, Oshima Y (eds) The new guideline for risk management measures for shellfish toxins and investigation on its implementation. Koseisha-Koseikaku, Tokyo, pp 109-126 (in Japanese)

Kamiyama T, Nagai S, Suzuki T, Miyamura K (2010) Effect of temperature on production of okadaic acid, dinophysistoxin-1, and pectin-2 by Dinophysis acuminata in culture experiments. Aquat Microb Ecol 60:193-202

Kamiyama T, Yamauchi H, Nagai S, Yamaguchi M (2014) Differences in abundance and distribution of Alexandrium cysts in Sendai Bay, northern Japan, before and after the tsunami caused by the Great East Japan Earthquake. J Oceanogr 70:185-195

Kim HG (2006) Mitigation and controls of HABs. In: Granéli E, Turner JT (eds) Ecology of harmful algae. Ecological studies, vol 189. Springer-Verlag, Berlin, pp 327-338

Kim MC, Yoshinaga Y, Imai I, Nagasaki K, Itakura S, Ishida Y (1998) A close relationship between algicidal bacteria and termination of Heterosigma akashiwo (Raphidophyceae) blooms in Hiroshima Bay, Japan. Mar Ecol Prog Ser 170:25-32

Kim BH, Sang M, Hwang SJ, Han MS (2008) In situ bacterial mitigation of the toxic cyanobacterium Microcystis aeruginosa: implications for biological bloom control. Limnol Oceanogr Method 6:513-522
Kiritani K (1979) Pest management in rice. Ann Rev Entomol 24:279-312

Kiritani K (1997) Relationship between IPM and environment. Ann Rept Plant Prot North Japan 48:1-3 (in Japanese)

Kiritani K (2000) Integrated biodiversity management in paddy fields: shift of paradigm from IPN toward IBM. Integr Pest Manag Rev 5:175-183

Kodama I, Inaba N, Imai I (2017) Quorum sensing suggesting activities of algicidal bacteria that kill red tide raphidophyte Heterosigma akashiwo and Chattonella antiqua. In: JSGFS 85th Anniversary-Commemorative International Symposium "Fisheries Science for Future Generations", No. 05003

Kojima S, Miyashita Y, Hagiwara T, Yamaguchi A, Imai I (2016) Possible control strategy of cyanobacterial blooms by bacteria from reed (Phragmites australis) in lakes of Onuma QuasiNational Park, Hokkaido. Bull Fish Sci Hokkaido Univ 66:1928 (in Japanese with English abstract)

Kondo S, Nakao R, Iwataki M, Sakamoto S, Itakura S, Matsuyama Y, Nagasaki K (2012) Heterocapsa circularisquama coming up north-mass mortality of Pacific oysters due to its blooming at Lake Kamo in Sado Island, Japan. Nippon Suisan Gakkaishi 78:719-725 (in Japanese English abstract)

Kotani Y, Koyama A, Yamaguchi M, Imai I (1998) Distribution of resting cysts of the toxic dinoflagellate Alexandrium catenella and/or A. tamarense in the coastal areas of western Shikoku and Kyushu Japan. Bull Jpn Soc Fish Oceanogr 62:104-111 (in Japanese with English abstract)

Lee SO, Kato J, Takiguchi N, Kuroda A, Ikeda T, Mitsutani A, Ohtake H (2000) Involvement of an extracellular protease in algicidal activity of the marine bacterium Pseudoalteromonas sp. strain A28. Appl Environ Microbiol 66:4334-4339

Lee SY, Lee IW, Choi CI (2006) Seasonal changes of community structure of phytoplankton in three Korean seagrass beds. Ocean Polar Res 28:95-105

Liu J, Lewitus AJ, Kempton JW, Wilde SB (2008) The association of algicidal bacteria and raphidophyte blooms in South Carolina brackish detention ponds. Harmful Algae 7:184-193

MAFF (Ministry of Agriculture, Forestry and Fisheries) (2020) Fishery production amount 2018. Statics of Agriculture, Forestry and Fisheries (in Japanese)

Manage PM, Kawabata Z, Nakano S (2001) Dynamics of cyanophage-like particles and algicidal bacteria causing Microcystis aeruginosa mortality. Limnology 2:73-78

Matsuyama Y, Miyamoto M, Kotani Y (1999) Grazing impact of the heterotrophic dinoflagellate Polykrikos kofoidii on a bloom of Gymnodinium catenatum. Aquat Microb Ecol 17:91-98

Matsuyama Y, Nishitani G, Nagai S (2010) Direct detection of harmful algae from the oyster spat and live fish transport trailers. In: Ho KC, Zhou MJ, Qi YZ (eds) Proceedings of XIII international conference on harmful algae. Hong Kong 2008, pp 185-189

Mayali X, Azam F (2004) Algicidal bacteria in the sea and their impact on algal blooms. J Eukaryot Microbiol 51:139-144

Meyer N, Bigalke A, Kaulfuß A, Pohnert G (2017) Strategies and ecological roles of algicidal bacteria. FEMS Microbiol Rev 41:880-899

Mikhail SK (2007) First monospecific bloom of the harmful raphidophyte Chattonella antiqua (Hada) Ono in Alexandria waters related to water quality and copepod grazing. Chem Ecol 23:393-407

Millennium Ecosystem Assessment (2007) Ecosystems and human well-being: Synthesis. In: World Resource Institute, Island Press, Washington DC (21st Century COE Translation Committee of Yokohama National University, Ohmsha, Tokyo) (in Japanese)

Mine H, Nagano A, Suenaga S, Imai I (2015) Possibility of civil engineering methods for countermeasures against harmful algal 
blooms. In: Proceedings of 2015 Conference of Japanese Society of Fisheries Engineering, pp 49-52 (in Japanese)

Mitsutani A, Uchida A, Ishida Y (1987) Occurrence of blue-green algae and algal lytic bacteria in Lake Biwa. Bull Jpn Soc Microb Ecol 2:21-28

Miyamura K (2016) Population dynamics, prediction and countermeasures of Karenia mikimotoi red tides. In: Imai I, Yamaguchi M, Matsuoka K (eds) Advances in harmful algal bloom research. Koseisha-Koseikaku, Tokyo, pp 191-200 (in Japanese)

Miyamura K (2017) Trial of Karenia mikimotoi red tide control with thin layer disturbance using growth suppression device. Aquaculture Business 54(11):49-52 (in Japanese)

Miyashita Y, Hagiwara T, Imai I (2019) The existence of cyanobactericidal bacteria and growth-inhibiting bacteria on water plants in Lake Ohnuma, Japan. Limnology 20:39-53

Mukai H (2011) Restoration project for tidal flats and seagrass bed: The critique. AIRIES 16:53-60 (in Japanese)

Murata K (2017) Mechanisms of the effects of clay dispersion on red tide control and development of improved clay. Aquacult Bus 54(3):17-19 (in Japanese)

Naba K (2001) Recent problems in pest management technologies on crop field-ideals, realities and prospects of integrated pest management in Japan. J Pesticide Sci 26:399-407 (in Japanese)

Nagai S (2007) Population structures of toxic Alexandrium and clarification of the dispersal mechanisms. In: Imai I, Fukuyo Y, Hiroishi S (eds) Advanced researches on shellfish poisonings: current status and overview. Koseisha-Koseikaku, Tokyo, pp 85-99 (in Japanese)

Nagai S, Lian CL, Yamaguchi S, Hamaguchi M, Matsuyama Y, Itakura S, Shimada H, Kaga S, Yamauchi S, Sonda Y, Nishikawa T, Kim CH, Hogetsu T (2007) Microsatellite markers reveal population genetic structure of the toxic dinoflagellate Alexandrium tamarense (Dinophyceae) in Japanese coastal waters. J Phycol 43:43-54

Nagai S, Nishitani G, Tomaru Y, Yamaguchi M, Kamiyama T (2008) Predation on the ciliate Myrionecta rubra by the toxic dinoflagellate Dinophysis fortii and observation of sequestration of ciliate chloroplasts. J Phycol 44:909-922

Nagai S, Sildever S, Suzuki T, Nishitani G, Basti L, Kamiyama T (2020) Growth and feeding behavior of mixotrophic Dinophysis species in laboratory cultures. In: Durvasula SRV (ed) Dinoflagellates: classification, evolution, physiology and ecological significance. Nova Publishers, New York (in press)

Nagasaki K (2008) Dinoflagellates, diatoms, and their viruses. J Microbiol 46:235-243

Nagasaki K, Yamaguchi M, Imai I (2000) Algicidal activity of a killer bacterium against the harmful red tide dinoflagellate Heterocapsa circularisquama isolated from Ago Bay, Japan. Nippon Suisan Gakkaishi 83:659-663 (in Japanese with English abstract)

Nagasaki K, Tomaru Y, Shirai Y, Takao Y, Mizumoto H (2006) Dinoflagellate-infecting viruses. J Mar Biol Ass UK 86:469-474

Nakai S, Inoue Y, Hosomi M, Murakami A (2000) Growth inhibition of blue-green algae (Microcystis aeruginosa) by Miriophyllum specatum-releasing four polyphenols. Water Res 34:3026-3032

Nakamura Y, Yamazaki Y, Hiromi J (1992) Growth and grazing of a heterotrophic dinoflagellate, Gyrodinium dominans, feeding on a red tide flagellate, Chattonella antiqua. Mar Ecol Prog Ser $82: 275-279$

Nakamura Y, Suzuki S, Hiromi J (1996) Development and collapse of a Gymnodinium mikimotoi red tide in the Seto Inland Sea. Aquat Microb Ecol 10:131-137

Nakanishi K (2002) Environmental remediation of coastal area for biological productivity. In: Matsuda O, Furuya K, Taniguchi $\mathrm{K}$, Hino A (eds) Role of fisheries in environmental management and remediation. Koseisha-Koseikaku, Tokyo, pp 60-70 (in Japanese)
Nakaoka M, Tamaki H, Muraoka D, Tokuoka M, Komatsu T, Tanaka N (2017) Temporal changes in seagrass beds of Sanriku Coast before and after the Great East Japan Earthquake. Nippon Suisan Gakkaishi 83:659-663 (in Japanese with English abstract)

Nakashima T, Miyazaki Y, Matsuyama Y, Muraoka W, Yamaguchi K, Oda T (2006) Producing mechanism of an algicidal compound against red tide phytoplankton in a marine bacterium $\gamma$-proteobacterium. Appl Microbiol Biotechnol 73:684-690

Nakayama N, Hamaguchi M, Yamaguchi H, Masuda K, Fujiwara M (2020) Evaluation of a virus-based control method to protect cultured oysters from the harmful dinoflagellate Heterocapsa circularisquama. Aquaculture 529:735625

Natsuike M, Kanamori M, Baba K, Moribe K, Yamaguchi A, Imai I (2014) Changes in abundances of Alexandrium tamarense resting cysts after the tsunami caused by the Great East Japan Earth Quake in Funka Bay, Hokkaido, Japan. Harmful Algae 39:271-279

Ndlela LL, Oberholster PJ, Van Wyk JH, Cheng PH (2018) Bacteria as biological control agents of freshwater cyanobacteria: is it feasible beyond the laboratory? Appl Microbiol Biotech 102:9911-9923

Nemoto F, Fukuhara H (2012) The antagonistic relationship between chlorophyll $a$ concentrations and the growth areas of Trapa during summer in a shallow eutrophic lake. Limnology 13:289-299

Nishi H, Tahara Y, Tokunaga S, Kubo M, Yoshimitsu S, Nakamura A (2012) Chattonella antiqua red tide occurred in Yatsushiro Sea in 2009 and 2010 - environmental characteristics and effects on farmed yellowtail. Bull Kagoshima Pref Fish Tech Dev Cen 3:5-20 (in Japanese)

Nishikawa T, Hori Y, Nagai S, Miyahara K, Nakamura Y, Harada K, Tada K, Imai I (2014) Long-term (36 year) observations on the dynamics of the fish-killing raphidophyte Chattonella in HarimaNada, eastern Seto Inland Sea, Japan. J Oceanogr 70:153-164

Nishitani G, Nagai S, Baba K, Kiyokawa S, Kosaka Y, Miyamura K, Nishikawa N, Sakurada K, Shinada A, Kamiyama T (2010) High-level congruence of Myrionecta rubra prey and Dinophysis species plastid identities as revealed by genetic analyses of isolates from Japanese coastal waters. Appl Environ Microbiol 76:2791-2798

Nishitani G, Ishikawa A, Kosaka Y, Imai I (2016) Field ecology of the toxic dinoflagellate Dinophysis causing diarrhetic shellfish poisoning. In: Imai I, Yamaguchi M, Matsuoka K (eds) Advances in harmful algal bloom research. Koseisha-Koseikaku, Tokyo, pp 272-281 (in Japanese)

O'Neil JM, Davis TW, Burford MA, Gobler CJ (2012) The rise of harmful cyanobacteria bloom: the potential roles of eutrophication and climate change. Harmful Algae 14:313-334

Oda M (1935) Gymnodinium mikimotoi Miyake et Kominami n. sp. (MS.) no Akashiwo to ryusando no koka (The red of Gymnodinium mikimotoi Miyake et Kominami n. sp. (MS) and the influence of copper sulfate on the red tide). Zool Mag 47:35-48 (in Japanese)

Ohta K (2018) Scientific mechanism of the effects of feeding stop on reduction of fish mortalities by red tides. Aquacult Bus 55(3):5156 (in Japanese)

Okaichi T (2004) Red-tide phenomena. In: Okaichi T (ed) Red tides. TERRAPUB/Kluwer, Tokyo, pp 7-60

Onishi Y, Mohri Y, Tuji A, Ohgi K, Yamaguchi A, Imai I (2014) The seagrass Zostera marina harbors growth-inhibiting bacteria against the toxic dinoflagellate Alexandrium tamarense. Fish Sci 80:353-362

Onishi Y, Tuji A, Yamaguchi A, Imai I (2021) Distribution of growth-inhibiting bacteria against the toxic dinoflagellate Alexandrium catenella (Group I) in Akkeshi-Ko Estuary and 
Akkeshi Bay, Hokkaido Japan. Appl Sci 11:172. https://doi. org/10.3390/app11010172

Onitsuka G, Aoki K, Shimizu M, Matsuyama Y, Kimoto K, Matsuo H, Kitadai Y, Nishi H, Tahara Y, Sakurada K (2011) Short-term dynamics of a Chattonella antiqua bloom in the Yatsushiro Sea, Japan, in summer 2010: characteristics of its appearance in the southern area. Bull Jpn Soc Fish Oceanogr 75:143-153 (in Japanese with English abstract)

Onitsuka G, Orita K, Sakurada K, Aoki K (2016) Monitoring and modeling of harmful algal blooms: a case study of Chattonella blooms in the Yatsushiro Sea. In: Imai I, Yamaguchi M, Matsuoka K (eds) Advances in harmful algal bloom research. Koseisha-Koseikaku, Tokyo, pp 153-162 (in Japanese)

Orth RJ, Carruthers TJB, Dennison WC, Duarte CM, Fourqurean JW, Heck KL Jr, Hughes AR, Kendrick GA, Kenworthy WJ, Olyarnik S, Short FT, Waycott M, Williams SL (2006) A global crisis for seagrass ecosystems. Bioscience 56:987-996

Paerl HW, Otten TG (2013) Harmful cyanobacterial blooms: causes, consequences, and controls. Microb Ecol 65:995-1010

Pal M, Pal S, Qureshi A, Sangolkar LN (2018) Perspective of cyanobacterial harmful algal bloom (HAB) mitigation: Microcystis toxin degradation by bacterial consortia. Ind J Exp Biol 56:511-518

Park MG, Kim S, Kim HS, Myung G, Kang YG, Yih W (2006) First successful culture of the marine dinoflagellate Dinophysis acuminata. Aquat Microb Ecol 45:101-106

Park JH, Yoshinaga I, Nishikawa T, Imai I (2010) Algicidal bacteria in particle-associated form and in free-living form during a diatom bloom in the Seto Inland Sea, Japan. Aquat Microb Ecol 60:151-161

Park TG, Lim WA, Park YT, Lee CK, Jeong HJ (2013) Economic impact, management and mitigation of red tides in Korea. Harmful Algae 30S:S131-S143

Rensel JEJ, Haigh N, Tynan TJ (2010) Fraser river sockeye salmon marine survival decline and harmful blooms of Heterosigma akashiwo. Harmful Algae 10:98-115

Sakami T, Sakamoto S, Takagi S, Inaba N, Imai I (2017) Distribution of three algicidal Alteromonas strains in seagrass beds and surrounding areas in the Seto Inland Sea, Japan. Fish Sci 83:113-121

Sakamoto S, Lim WA, Lu D, Dai X, Orlova T, Iwataki M (2021) Harmful algal blooms and associated fisheries damage in east Asia: current status and trends in China, Japan, Korea and Russia. Harmful Algae 102:101787. https://doi.org/10.1016/j. hal.2020.101787

Sakata T, Yoshikawa T, Nishitarumizu S (2011) Algicidal activity and identification of an algicidal substance produced by marine Pseudomonas sp. C55a-2. Fish Sci 77:397-402

Schallenberg M, Sorrel B (2009) Regime shifts between clear and turbid water in New Zealand lakes: environmental correlates and implications for management and restoration. N Z J Mar Freshw Res 43:701-712

Scheffer M, Jeppesen E (2007) Regime shifts in shallow lakes. Ecosystems 10:1-3

Scheffer M, van den Berg M, Breukelaar A, Breukers C, Coops H, Meijer ML (1994) Vegetated areas with clear water in turbid shallow lakes. Aquat Bot 49:193-196

Scheffer M, Carpenter S, Foley JA, Folke C, Walker B (2001) Catastrophic shifts in ecosystems. Nature 413:591-596

Seger A, Park TG, Hallegraeff G (2017) Assessment of the efficacy of clay flocculation in Korean fish farm waters: Cochlodinium cell removal and mitigation of ichthyotoxicity. Harmful Algae 61:46-55

Shikata T, Sakurada K, Jomoto Y, Oyama N, Onji M, Yoshida M, Ohwada K (2011) Growth dynamics of Chattonella antiqua in relation to nutrients in the Yatsushiro Sea. Nippon Suisan Gakkaishi 77:40-52 (in Japanese with English abstract)

Shimada H, Sakamoto S, Yamaguchi M, Imai I (2016a) First record of two warm-water HAB species Chattonella marina (Raphidophyceae) and Cochlodinium polykrikoides (Dinophyceae) on the west coast of Hokkaido, northern Japan in summer 2014. Reg Stud Mar Sci 7:111-117

Shimada H, Kanamori M, Yoshida H, Imai I (2016b) First record of red tide due to the harmful dinoflagellate Karenia mikimotoi in Hakodate Bay, southern Hokkaido, in autumn 2015. Nippon Suisan Gakkaishi 82:934-938 (in Japanese with English abstract)

Shimizu T, Ueshiro H, Ito H (2016) Succession of biological disorder caused by phytoplankton. J Water Waste 58:503-508 (in Japanese)

Shimizu T, Oda T, Ito H, Imai I (2017) Isolation and characterization of algicidal bacteria and its effect on a musty odor-producing cyanobacterium Dolichospermum crassum in a reservoir. Water Sci Technol Water Supply 17:792-798

Shirota A (1989) Red tide problem and countermeasures (2). Int J Aquat Fish Technol 1:195-223

Sigee DC, Glenn R, Andrews MJ, Bellinger EG, Butler RD, Epton HAS, Hendry RD (1999) Biological control of cyanobacteria: principles and possibilities. Hydrobiologia 395(396):161-172

Sonsangjinda P, Matsuda O, Yamamoto T, Rajendran N, Maeda H (2000) The role of suspended oyster culture on nitrogen cycle in Hiroshima Bay. J Oceanogr 56:223-231

Steffen MM, Davis TW, McKay RML, Bullerjahn GS, Krausfeldt LE, Stough JMA, Neitzey ML, Gilbert NE, Boyer GL, Johengen TH, Gossiaux DC, Burtner AM, Palladino D, Rowe MD, Dick GJ, Meyer KA, Levy S, Boone BE, Stumpf RP, Wynne TT, Zimba PV, Gutierrez D, Wilhelm SW (2017) Ecophysiological examination of the Lake Erie Microcystis bloom in 2014: Linkages between biology and the water supply shutdown of Toledo, $\mathrm{OH}$. Environ Sci Technol 51:6745-6755

Stewart I, Seawright AA, Shaw GR (2008) Chapter 28: Cyanobacterial poisoning in livestock, wild animals and birds-an overview. In: Hudnell HK (ed) Cyanobacterial harmful algal blooms: State of the science and research needs, Advances in experimental medicine and biology, vol 619. Springer, pp 613-617

Suzuki T (2017) Contamination of bivalves with shellfish toxins by toxic phytoplankton and the monitoring system of shellfish toxins. In: Suzuki T, Kamiyama T, Oshima Y (eds) The new guideline for risk management measures for shellfish toxins and investigation on its implementation. Koseisha-Koseikaku, Tokyo, pp 9-26 (in Japanese)

Takahashi M, Seibert DL, Thomas WH (1977) Occasional blooms of phytoplankton during sumer in Saanich Inlet, BC, Canada. DeepSea Res 24:775-780

Takamura N (1988) Ecology of water-blooms of blue-green algae, with special reference to Microcystis. Jpn J Phycol 36:65-79 (in Japanese with English abstract)

Tanabe T, Kaga Y (2017) Shellfish toxins in Tohoku coastal areas: its changes and trends after the Great East Japan Earthquake in 2011. In: Suzuki T, Kamiyama T, Oshima Y (eds) The new guideline for risk management measures for shellfish toxins and investigation on its implementation. Koseisha-Koseikaku, Tokyo, pp 127-139 (in Japanese)

Tanaka S, Aoyama S, Imai M, Osaka S, Takabayashi N (1985) Effects of hanging depth and vitality of scallop on toxicity of diarrheal shellfish poisoning. Ann Rep Aomori Pref Fish Aquacult Center 14:259-268

Teegarden GJ, Cembella AD (1996) Grazing of toxic dinoflagellates, Alexandrium spp., by adult copepods of coastal Maine: Implications for the fate of paralytic shellfish toxins in marine food webs. J Exp Mar Biol Ecol 196:145-176 
Tomaru Y, Katanozaka N, Nishida K, Shirai Y, Tarutani K, Yamaguchi M, Nagasaki K (2004) Isolation and characterization of two distinct types of HcRNAV, a single-stranded RNA virus infecting the bivalve-killing microalga Heterocapsa circularisquama. Aquat Microb Ecol 34:207-218

Tomaru Y, Shirai Y, Nagasaki K (2007) Ecology, physiology and genetics of a phycodnavirus infecting the noxious bloom-forming raphidophyte Heterosigma akashiwo. Fish Sci 74:701-711

Trainer VL, Moore SK, Hallegraeff G, Kudela RM, Clement A, Mardones JI, Cochlan WP (2020) Pelagic harmful algal blooms and climate change: Lessons from nature's experiments with extremes. Harmful Algae 91:101591

Turner JT, Tester PA (1997) Toxic marine phytoplankton, zooplankton grazers, and pelagic food webs. Limnol Oceanogr 42:1203-1214

Uchida T, Toda S, Nakamura O, Abo K (1998) Initial site of Gymnodinium mikimotoi blooms in relation to the seawater exchange rate in Gokasho Bay, Japan. Plankton Biol Ecol 45:129-137

Umetsu S, Kanda M, Imai I, Sakai R, Fujita MJ (2019) Questiomycins, algicidal compounds produced by the marine bacterium Alteromonas sp. D and their production cue. Molecules 24:4522. https://doi.org/10.3390/molecules24244522

Uye S (1986) Impact of copepod grazing on the red-tide flagellate Chattonella antiqua. Mar Biol 92:35-43

Uye S, Takamatsu K (1990) Feeding interactions between planktonic copepods and red-tide flagellates from Japanese coastal waters. Mar Ecol Prog Ser 59:97-107

Wells ML, Karlson B, Wulff A, Kudela R, Trick C, Asnaghi V, Berdalet E, Cochlan W, Davidson K, De Rijcke M, Dutkiewicz S, Hallegraeff G, Flynn KJ, Legrand C, Paerl H, Silke J, Suikkanen S, Thompson P, Trainer VL (2020) Future HAB science: directions and challenges in a changing climate. Harmful Algae 91:101632

White A (1981) Marine zooplankton can accumulate and retain dinoflagellate toxins and cause fish kills. Limnol Oceanogr 26:103-109

White A, Fukuhara O, Anraku M (1989) Mortality of fish larvae from eating toxic dinoflagellates or zooplankton containing dinoflagellate toxins. In: Okaichi T, Anderson DM, Nemoto T (eds) Red Tides: Biology, Environmental Science, and Toxicology. Elsevier, NY, pp 395-398

Yamaguchi M (1994) Physiological ecology of the red tide flagellate Gymnodinium nagasakiense (Dinophyceae) — mechanism of the red tide occurrence and its prediction. Bull Nansei Natl Fish Res Inst 27:251-394

Yamaguchi M, Itakura S, Imai I, Ishida Y (1995a) A rapid and precise technique for enumeration of resting cysts of Alexandrium spp. (Dinophyceae) in natural sediments. Phycologia 34:207-214

Yamaguchi M, Itakura S, Imai I (1995b) Vertical and horizontal distribution and abundance of resting cysts of the toxic dinoflagellate Alexandrium tamarense and Alexandrium catenella in sediments of Hiroshima Bay, the Seto Inland Sea, Japan. Nippon Suisan Gakkaishi 61:700-706 (in Japanese with English abstract)

Yamaguchi M, Itakura S, Nagasaki K, Kotani Y (2002) Distribution and abundance of resting cysts of the toxic Alexandrium spp. (Dinophyceae) in sediments of the western Seto Inland Sea Japan. Fish Sci 68:1012-1019
Yamamoto Y (1988) Cyanobacteria-lysing agents and their distribution patterns of lakes and rivers in Japan. Bull Jpn Soc Microb Ecol 2:77-88 (in Japanese with English abstract)

Yamamoto T (2003) The Seto Inland Sea-eutrophic or oligotrophic? Mar Poll Bull 47:37-42

Yamamoto K, Nakajima M, Tabuchi K, Hamano Y (2009a) A novel red tide of the toxic dinoflagellate Alexandrium tamarense and resultant contamination of paralytic shellfish toxins in bivalves in the spring of 2007 in Osaka Bay. Bull Plankton Soc Japan 56:13-24 (in Japanese with English abstract)

Yamamoto K, Nabeshima Y, Yamaguchi M, Itakura S (2009b) Distribution and abundance of resting cysts of the toxic dinoflagellates Alexandrium tamarense and A. catenella in 2006 and 2007 in Osaka Bay. Bull Jpn Soc Fish Oceanogr 73:57-66 (in Japanese with English abstract)

Yamamoto K, Ohmi H, Sano M (2011) Occurrence of a red tide of the toxic dinoflagellate Alexandrium tamarense in the estuary of the Yodo River in 2007-dynamics of the vegetative cells and the cysts. Bull Plankton Soc Japan 58:136-145 (in Japanese with English abstract)

Yamamoto K, Tsujimura H, Nakajima M, Harrison PJ (2013) Flushing rate and salinity may control the bloom of the toxic dinoflagellate Alexandrium tamarense in a river/estuary in Osaka Bay, Japan. J Oceanogr 69:727-736

Yamamoto K, Nakajima M, Imai I (2017) Expansion of blooming in the toxic dinoflagellate Alexandrium tamarense and environmental fluctuation analyzed from long-term monitoring data in Osaka Bay, eastern Seto Inland Sea, Japan. Bull Plankton Soc Japan 64:11-21 (in Japanese with English abstract)

Yanagi T (2006) Sato-Umi ron (Sato-Umi theory). Koseisha-Koseikaku, Tokyo, p 102 (in Japanese)

Yanagi T (2008) "Sato-Umi"- - a new concept for sustainable fisheries. In: Tsukamoto K, Kawamura T, Takeuchi T, Beard Jr TD, Kaiser MJ (eds) Fisheries for global welfare and environment, 5th world fisheries congress 2008. TERRAPUB, Tokyo, pp 351-358

Yasumoto T, Nakajima I, Bagnis R, Adachi R (1977) Finding of a dinoflagellate as a likely culprit of ciguatera. Bull Jpn Soc Sci Fish 43:1021-1026

Yih W, Kim HS, Jeong HJ, Myung G, Kim YG (2004) Ingestion of cryptophyte cells by the marine photosynthetic ciliate Mesodinium rubrum. Aquat Microb Ecol 36:165-170

Yoshinaga I, Kim MC, Katanozaka N, Imai I, UchidaI A, Ishida Y (1998) Population structure of algicidal marine bacteria targeting the red tide forming alga Heterosigma akashiwo (Raphidophyceae), determined by restriction fragment length polymorphism analysis of the bacterial 16S ribosomal RNA genes. Mar Ecol Prog Ser 170:33-44

Publisher's Note Springer Nature remains neutral with regard to jurisdictional claims in published maps and institutional affiliations. 